\title{
An Integrated Approach to Control the Black Leaf Streak Disease (BLSD) of Bananas, while Reducing Fungicide Use and Environmental Impact
}

\author{
Jacky Ganry $^{1}$, Eric Fouré2 ${ }^{2}$ Luc de Lapeyre de Bellaire ${ }^{2}$ and Thierry Lescot ${ }^{2}$ \\ 1 International Cooperation, Agreenium, CIRAD, \\ ${ }^{2}$ CIRAD- Persyst, UPR 'Systèmes de culture bananiers, plantains et ananas', Montpellier,
}

France

\section{Introduction}

This chapter aims at describing an integrated approach to control the development of Black Leaf Streak Disease(BLSD) of bananas and plantains plants with a minimum of fungicide applications resulting in lower cost of control, lower risk of fungicide resistance and lower environmental negative impact.

Bananas are one of the main agricultural productions in the world, and the main fruit crop, with an annual production of about $117 \mathrm{Mt}$ (Lescot, 2011). International trade of bananas represents $14 \mathrm{Mt}$ year-1 with a value of more than 4 billion US\$ (Loeillet, 2005). The production of bananas for this international trade is grown in a small number of tropical countries mainly located in Latin America $(80 \%)$, in African and Asian countries, and in the European community (French West Indies, Canary Islands). In all these countries, this industry is economically important and a source of direct and indirect employment. But one of the main problems is that it relies on a very narrow genetic base, the Cavendish subgroup, which is exposing the industry to important pest and disease threats.

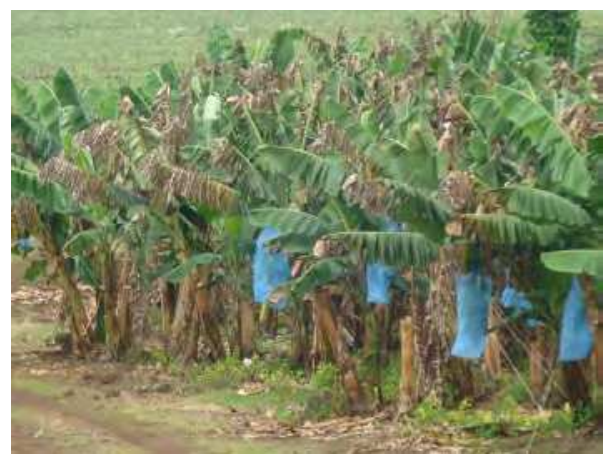

Photo credit: CARBAP (J. Ngando)

Photo 1. Banana plants with necrosis of BLSD . 
The Banana leaf spot diseases are a major constraint in most large production areas, resulting in very significant losses in the absence of suitable control system (Stover, 1986; Stover \& Simmonds, 1987). There are two major impacts of the disease on the production.

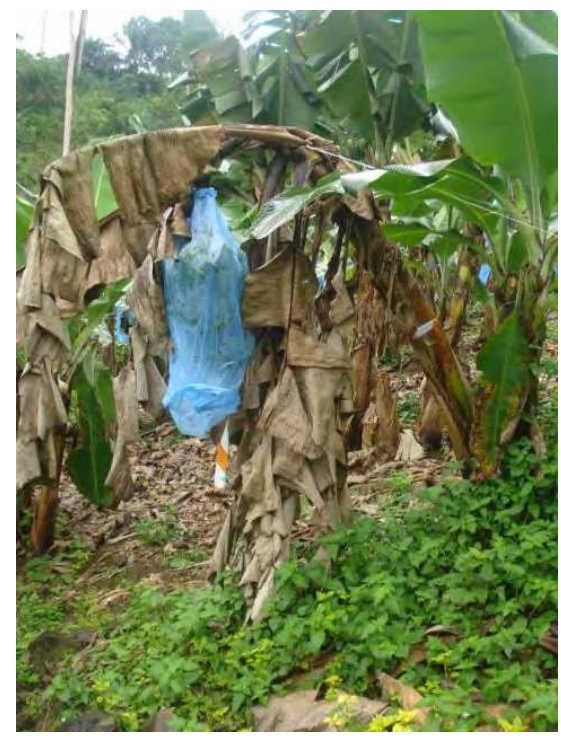

Photos credit: CARBAP (J. Ngando)

Photo 2. Very severe attack of BLSD on a banana plant with a bunch

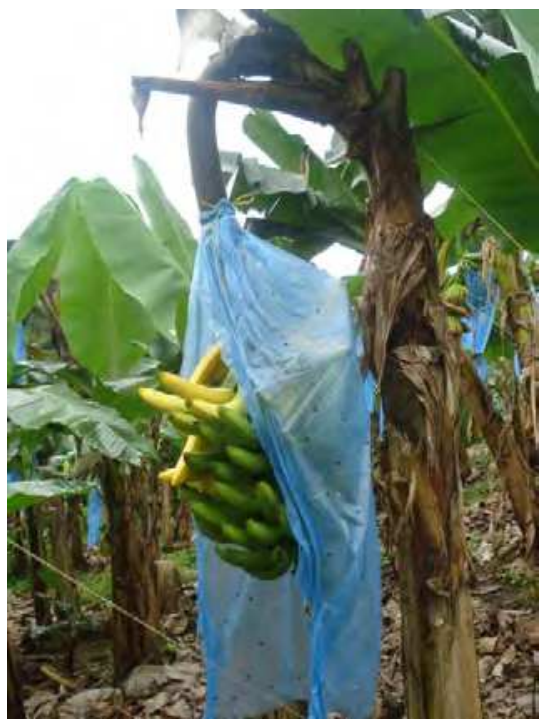

Photos credit: CARBAP (J. Ngando)

Photo 3. Early ripening of the fruits due to severe attack of BLSD 
The first one is a reduction of yield due to a negative effect on the photosynthetic assimilation (up to 50 to $100 \%$ ) and thus on dry matter production. Bunch weight is strongly affected (Ramsey \& Daniells, 1990), and significant yield losses (20\% to 50\%) were observed on plantains (Stover, 1983; Mobambo et al., 1996).

A second one is a reduction of the conservation potential of the fruit, expressed by its "greenlife", which is the time between harvest and ripening, arguing for a direct effect of these foliar diseases on fruit physiology by mechanisms that remain to be discovered (Abadie et al., 2008; Chillet et al., 2009). The impact on export quality is thus very critical as there are high risks of advanced maturation (Stover, 1972). Therefore banana growers must control BLSD to a level that does not alter fruit exportation.

The economic incidence of BLSD is important since the cost of control can reach more than $25 \%$ of the production cost (Stover \& Simmonds, 1987) and the BLSD incidence in the banana industry is regularly increasing.

Two species are responsible for the current epidemics, Mycosphaerella musicola Leach, causal agent of the Sigatoka Leaf Spot Disease (SLSD) and Mycosphaerella fijiensis, causal agent of the Black Leaf Streak Disease (BLSD). The latter is much more virulent than the former resulting in more intense damage and more difficult control. In addition the spectrum of susceptible varieties is much wider. The group of plantains is particularly susceptible to BLSD when it is considered resistant to SLSD, except in special geographical conditions (altitude zones) (Fouré \& Lescot, 1988).

BLSD is regarded as the most economically important disease (Jones, 2000) for the banana industry and it is a major constraint for small farmers growing banana and plantains for domestic markets (Marin et al., 2003). It is considered as one of the most important crop diseases in the world (Pennisi, 2010).

Such a situation is mainly related to the fact that the banana trade relies on a unique group of banana cultivars (Musa acuminata, AAA, Cavendish subgroup) which are highly susceptible to this disease.

BLSD is present in Latin America since 1972, in Cameroon since 1980 and has appeared in Ivory Coast in 1985. Its expansion in the Caribbean is more recent having started from two independent introductions in the north (Cuba in 1990, and then Jamaica, the Dominican Republic, Haiti and Puerto Rico) and in the Lesser Antilles (through Trinidad in 2003) with a very recent arrival in Martinique (2010).

The life cycle of BLSD has been widely described and starts with leaf infection by either ascospores or conidia (Fig. 1) It is important to highlight the main characteristics of this life cycle that are useful for BLSD control.

After a period of epiphyllic growth of generally 2-3 days, germ tubes penetrate stomata. In good conditions, the first symptoms appear generally 10-14 days after. The symptoms then gradually evolve from stage 1 to stage 6 (Fouré, 1982)

Conidia are produced on young stages of the disease (stage2-4) and have been considered as water dispersed at short distances, even if they are also present in the "airspora". Ascospores are produced at later stage and wind-dispersed after perithecia burst. They are considered to be dispersed at longer distances than conidia. 


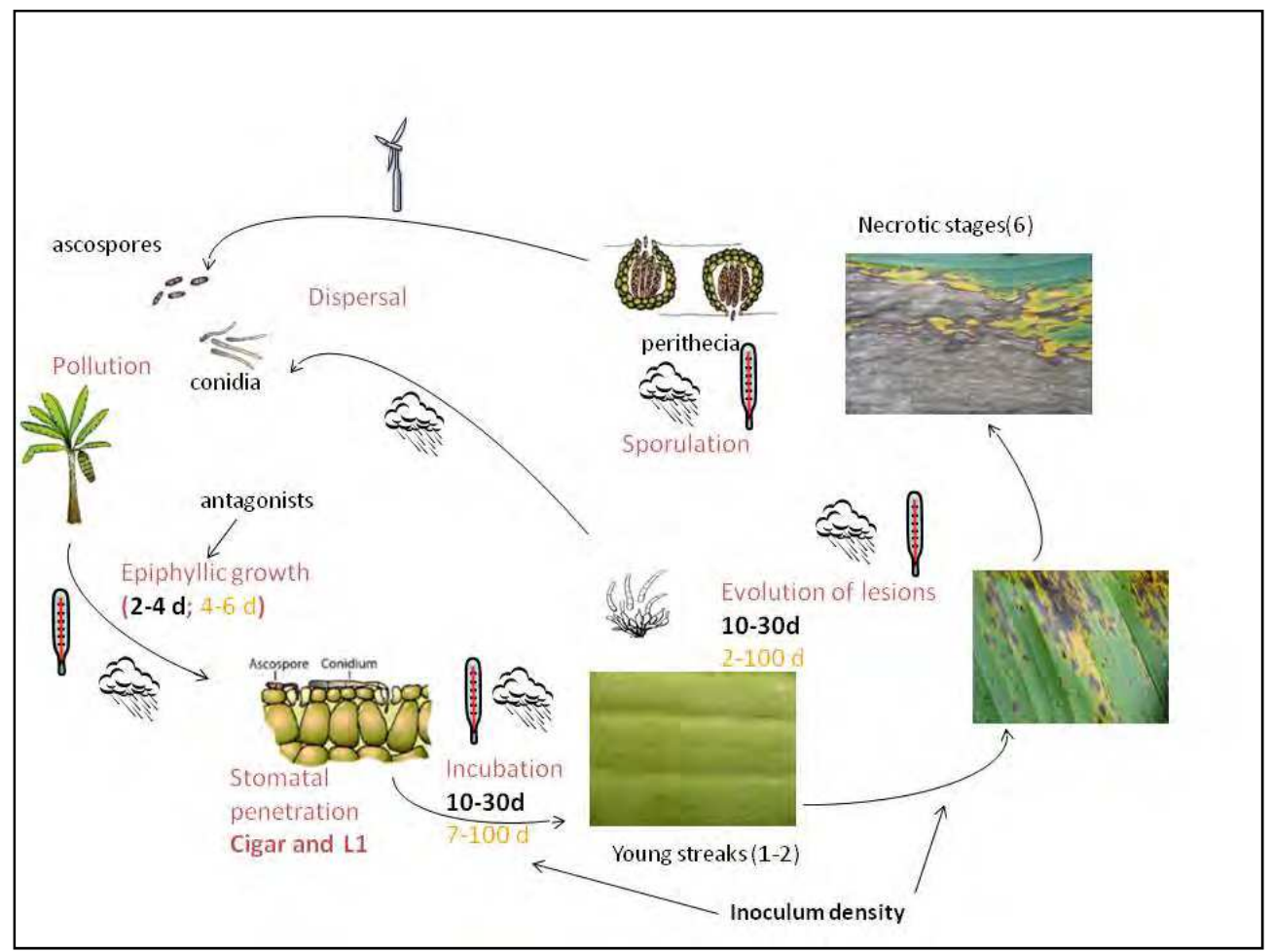

(in yellow: data for the Sigatoka Disease and in black, data for the BLSD)

Fig. 1. The biological cycle of the banana leaf spot diseases

\section{Principle and various components of an integrated approach to control BLSD of bananas}

The principle and various components of this integrated approach are presented. They are based on a holistic approach including technical aspects and logistical, economic and political aspects as well.

\subsection{Historical features}

It is useful to look at some historical features to better understand the genesis of this integrated control of BLSD.

An effective chemical control of SLSD, based on the use of mineral oils, was developed by a French team of IFAC in Guadeloupe in the fifties (Guyot \&Cuillé, 1954; Guyot \&Cuillé, 1955).

The work done at that time quickly showed that the foliar emission rate of the banana plant would impose a very large number of sprays to ensure that each new leaf is protected in time. This should lead to a minimum of forty sprays per year with an additional processing constraint to apply about 2000 liters of aqueous formulation per hectare, which was quite intolerable. 


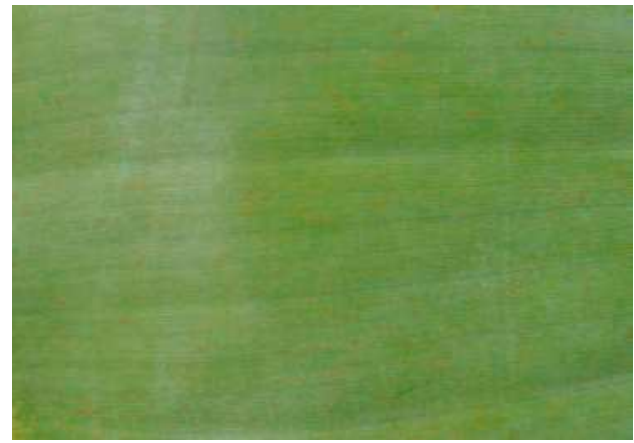

Photo 4 . Stages 1 and 2 of the disease (adaxial surface)

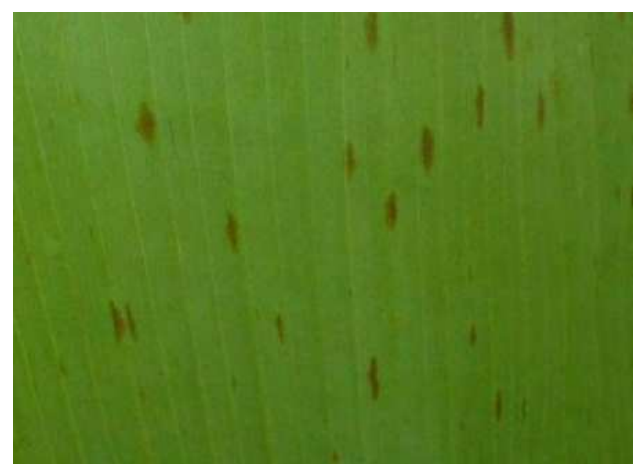

Photo 6. Stages 4 (adaxial surface)

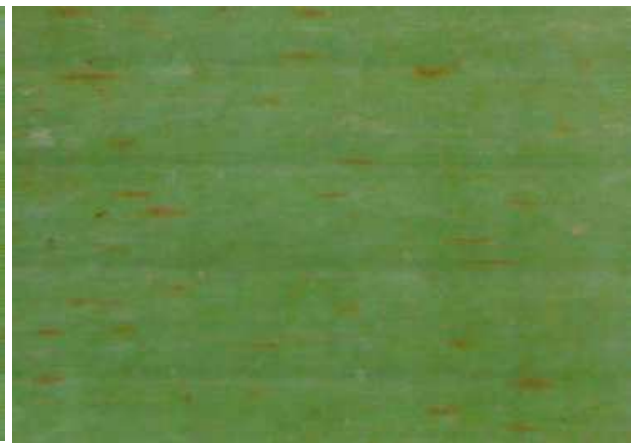

Photo 5. Stages 2 and 3 of the disease (adaxial surface)

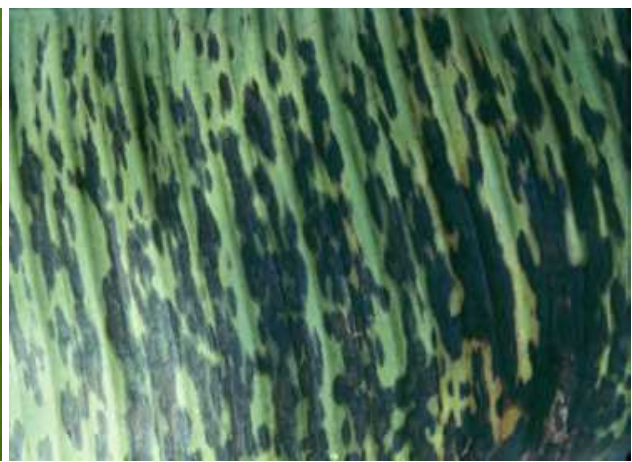

Photo 7. Stages 5 of the disease (abaxial surface)

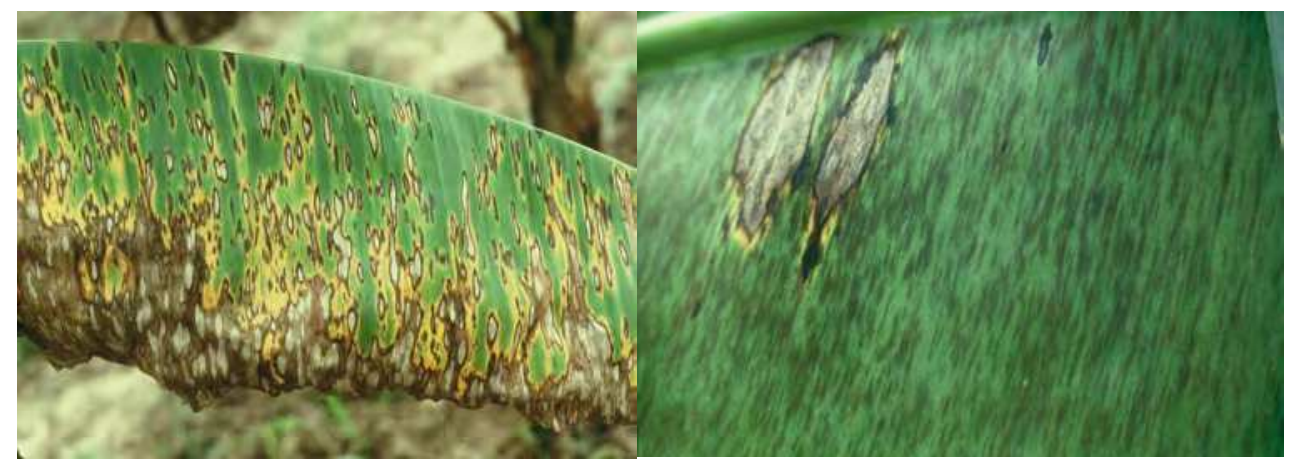

Photo 8. Stage 6 of the disease with perithecia (abaxial surface).
Photo 9. The density of infection is often very important resulting in necrotic patches by coalescence.

Plate 1. Illustration of BLSD symptoms (Photo credit: Cirad /E.Fouré \& L. de Lapeyre de Bellaire) 
The research therefore looked for reducing these constraints i) by studying more closely the biology of the pathogen to intervene only when necessary ii) limiting the volume of mixture applied per hectare and the number of fungicide applications, iii ) focusing on the choice of more effective and persistent fungicides.

The first goal resulted in the development of disease observation and warning methods, with the early work conducted by Cuillé \& Guyot in 1954.

To reach the second goal, the work achieved made it possible to replace the copper formulations applied through ground sprays at a rate of 2000 liters per hectare by a low volume of mixtures, initially applied with ground sprayers and later by plane or helicopter, to go down to 15 liters per hectare. This development was made possible by the discovery of the qualities of mineral oils which have proven to be excellent vehicles for fungicides, either alone or mixed with water. These mineral oils (i) showed a fungistatic activity on the pathogen, (ii) ensured a good repartition of droplets at leaf surface and a good penetration of fungicides in the leaf tissues, (iii)avoided the rainfall leaching occurring after treatment.

As a matter of fact, before 1972, aerial and ground sprays were currently done only with oil. With the appearance of systemic fungicides in the 1970', new formulations were introduced coupling the fungistatic action of the oil with the strong curative action of currently marketed systemic fungicides (Ganry \& Laville, 1983). Fungicides used belong to different chemical families with different mode of actions such as benzimidazoles, triazoles, morpholins and more recently strobilurins (see Box 4), which have been used practically in this chronological order, taking into account the emergence of resistance of the fungus to benzimidazoles and triazoles..

Very soon appeared the need to abandon a strategy of systematic control and move towards less fungicide applications in order to (i) reduce production costs, (ii) reduce environmental impact and (iii) limit the occurrence of fungicide resistant strains. With such an objective of better management of the control strategy, CIRAD (formerly IRFA) has, since the seventies, focused its work on the development of a warning method in order to apply fungicides only when necessary.

The warning system used is based both on climatic data (Box 1) and on field observations of symptoms evolution in early stages (Box 2).

In Guadeloupe and Martinique, since the 70's, the information has been processed on an aggregate basis for each island and managed by a specialized team attached to the banana growers associations. Aerial sprays are made on a similar base and are generalized for the whole of each island.

As a result of the use of such a disease management strategy the control of the SLSD has been very satisfactory in the French Antilles since the seventies (Fig. 1), with a number of applications ranging from five to eight per year, while applications carried out systematically in similar situations would have required at least 10 to 15 treatments per year (Ganry, 2001).

This success story relies on some basic requirements:

- A generalized application over large geo-climatic areas including several growers,

- A very good spraying logistics in order to reduce as short as possible the period between the decision of the fungicide application according to the warning system and the completion of the spray. 
The characteristics of these two control methods are summarized in the table 1.

Box 2. The Stage of Evolution of the SLSD, SEDs (Ganry \& Meyer, 1972b; Ganry \& Laville, 1983; Ganry et al, 2008)

Its purpose is to get a biological descriptor of the speed of evolution of the disease, according to climatic conditions and inoculum pressure.

It is adapted to the forecast as it is based on the earliest visible detection of infection and it is directly connected to climatic conditions

Observation plots are designed to weekly check the same 10 to 30 homogenous banana plants during their vegetative phase (between 5 to 18 leaves).

The observation is purely qualitative: the youngest leaves (range 1 to 5 ) are checked every week, and the most advanced stage of the disease according to Brun's scales (Brun, 1963) is scored.

In addition, the cigar development (score fom A to E) observation provides the evaluation of the weekly
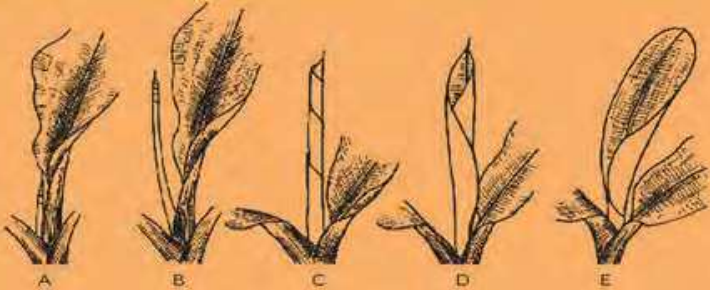

foliar emission rate.

The scoring of the disease is as follow from adaxial surface observations:

1.Stage 1: a spot is just visible to the naked eye as a minute yellowish-green speck less than $1 \mathrm{~mm}$.

2.Stage 2: the streak increases in size, notably in length, and remains yellowish-green, with a size superior

to $1-2 \mathrm{~mm}$.

3.Stage 3: a streak begins to broaden slightly and increases in length as well, and begins to turn into rusty red.

4.Stage 4: this is the first spot stage. The streak turns dark-brown, is sunken and has reached its final size. A water-soaked yellow halo forms around the spot. Conidia are formed at this stage.

5.Stage 5: this is the final stage of the lesion. The central area of the spot turns grey and the margins of the spot are black. Some minute black points are visible, to the naked eye or with a magnifying glass, in the central area. They correspond to perithecia and spermogonia where ascospores and spermatia are produced The couple leaf range/disease stage provides a coefficient that reflects the speed of evolution of the disease:

\begin{tabular}{|l|l|r|r|r|r|}
\hline \multirow{2}{*}{$\begin{array}{l}\text { Stage of the } \\
\text { disease }\end{array}$} & \multicolumn{4}{|l|}{ Leaf range } \\
\cline { 2 - 6 } & I & \multicolumn{1}{|c|}{ II } & \multicolumn{1}{|c|}{ III } & \multicolumn{1}{|c|}{ IV } & \multicolumn{1}{l|}{} \\
\hline 1 & 100 & 80 & 60 & 40 & 20 \\
\hline 2 & 120 & 100 & 80 & 60 & 40 \\
\hline 3 & & 120 & 100 & 80 & 60 \\
\hline 4 & & & 120 & 100 & 80 \\
\hline 5 & & & & 120 & 100 \\
\hline
\end{tabular}

In order to mitigate the scoring variations due to brutal change in leaf stage (equal at 20), a correction is done taking into account the cigar stage: for each leaf with symptoms (scoring $>0$ ), the following quantity is substracted: 4 for B, 8 for C, 12 for D and 16 for E.

As SEDs must be the expression of a growth speed, the couple "disease stage-leaf range" must be related to time through the leaf emission rate (LER), obtained by the current "leaf range-cigar stage" by the "leaf rangecigar stage" of the past week ( $\mathrm{LiCi}-\mathrm{L}(\mathrm{i}-1) \mathrm{C}(\mathrm{i}-1)$ with $\mathrm{iC}=.0$ for $\mathrm{A}, .2$ for $\mathrm{B}, 4$ for $\mathrm{C}, 6$ for $\mathrm{D}$ and 8 for $\mathrm{E})$

\subsection{The basic principle of an integrated approach to control the banana BLSD}

Inherited from this strong experience with the control of the SLSD, the integrated approach to control BLSD is based on the rational use of curative (systemic) fungicides applied in oil mixtures.

The sequence of fungicide sprays is driven by a forecasting system supported by biological indicators (Fouré \& Ganry, 2008; Ganry et al., 2008). Since M. fijiensis is more aggressive than $M$. musicola, the system works efficiently for this pathogen when the disease pressure is not too high. It is the reason why it must be supplemented by sanitation practices consisting in necrotic and pre-necrotic leaf removal in order to 
eliminate new sources of inoculum. Other crop practices must be introduced to synergize with fungicide sprays and leaf removal dealing with crop management: plant nutrition, crop density, water management.

Depending on the type of fungicide used and on the selection pressure ${ }^{1}$, there is always a risk of emergence of fungicide resistance in pathogen populations. It is one of the major reasons of the decrease of the chemical control efficiency which is often the starting point of a vicious circle.

Therefore it is highly important to monitor the pathogen sensitivity to the fungicides used. This monitoring must be considered as a key decision tool for the choice of appropriate fungicides (when it is possible) and their sequence in alternation, in order to minimize the selection pressure.

Such an approach was adopted for BLSD when it appeared in Gabon on plantains (see §2.2. BLSD control in Gabon in small scale plantain production for domestic markets) and in Cameroon (see \$2.2. BLSD control in Cameroon in the banana industry for export), Ivory Coast and Ecuador on banana and plantain. Thanks to a strong experience on SLSD control and to the implementation of such disease management strategies, BLSD in these countries has been properly controlled with an average of 10 to 15 treatments per year ${ }^{2}$.

In comparison, in some Latin American countries, the number of annual sprays can reach 30 to 60 (more than one per week) due to systematic fungicide applications and to the emergence of resistant strains to curative (systemic) fungicides that were used too frequently (Carlier et al., 2000; Romero \& Sutton, 1997). As a consequence more contact, non curative, fungicides are used (Table 1.).

\begin{tabular}{|l|l|}
\hline IRFA method & american method \\
\hline Oil used with a rate of 12-15 liters/ha with & $\begin{array}{l}\text { Water or oil-water emulsions (2 - 8 liters of } \\
\text { oil + 10-20 liters of water) with }\end{array}$ \\
curative (systemic) fungicide & $\begin{array}{l}\text { 1. Contact fungicide } \\
10 \text { to } 15 \text { sprays a year (depending on }\end{array}$ \\
location and inoculums) & $\begin{array}{l}\text { 3. Contact and curative fungicide } \\
30 \text { to } 60 \text { systematic sprays depending on } \\
\text { locations }\end{array}$ \\
\hline
\end{tabular}

Table 1. Compared characteristics of the IRFA and american methods for BLSD control

\subsubsection{Component 1: Timing of decisions through a biological forecasting}

The timing of decisions is based on a standardized set of criteria, taking into account the development of the fungus and the growth of the plant, both climate-driven. The first level

\footnotetext{
1 Related to the duration of the pathogen exposure to the fungicide

2 Cameroon: from 10 to 15 treatments / year have succeeded in the disease control for more than 10 years. However, the emergence of strains resistant to systemic fungicides, due to some failures in the implementation, is currently preventing the use of this disease management.

- Ivory Coast: control is achieved with 12-14 treatments / year in most production areas.

- Ecuador: from 10 to 12 treatments / year succeeded in disease control when this disease management strategy was experimented in this country in the late 80 's.
} 
of elaboration of reliable tools for strategic decisions is to implement a continuous monitoring of disease evolution in the field. It is also informative to fit these weekly data with weekly rainfall, in order to get a better appreciation of epidemiological conditions (de Lapeyre de Bellaire et al., 2010a).

- The Stage of Evolution of Disease of the BLSD, SEDb, is the main parameter that should be assessed. SEDb has been specifically designed for warning systems based on the early detection of new attacks, and has been specifically adapted from SLSD to BLSD (Fouré \& Ganry, 2008) taking into account the important density of symptoms leading to necrotic development by coalescence (see plate 1 \& box3). It is also a good indicator of the efficiency of the chemical control that is designed to reduce disease development in its early stages, that means on the youngest banana leaves (Fig. 3).

$\mathrm{SEDb}$ represents the speed of evolution of the disease, which reflects the climatic conditions and the intensity of the infection (Ganry \& Meyer, 1972b). The early detection of new attacks on the youngest leaves will allow blocking their evolution towards necroses thanks to the application of a curative fungicide. In order to maintain the field inoculum as low as possible, it is then essential to stop the disease evolution before necrotic formation because sexual sporulation starts in necrotic stages of the disease.

A larger set of disease parameters should also be used and evaluated continuously every week on the same banana plot used for the assessment of SEDb in order to provide complementary information:

- $\quad$ The 'Youngest Leaf bearing Streaks' (YLSt) is the position of the youngest leaf bearing symptoms of the disease. It reflects the incubation period of the disease under a spraying program, which depends on both climatic conditions and fungicide inhibition of the pathogen. Its evolution gives information on the epidemiological conditions and on the performance of the chemical strategy as well. YLSt is scored jointly with SEDb. If none of the 4 leaves monitored have symptoms, the symptoms should be looked for on the older leaves.

- The 'Youngest Leaf Spotted' (YLS) should be scored according to Stover's method (Stover, 1971) where the YLS is the youngest leaf bearing at least 10 necrotic lesions. However, if none of the leaves bear any necrotic lesion, the value of YLS will arbitrary be $\mathrm{N}+1$, where $\mathrm{N}$ is the total number of leaves of the banana tree. In addition, since the absolute value of the YLS is dependent of the phenological stage of the plant, all the banana plants monitored should be homogenous. Thus, better than the absolute value of the YLS we must consider its evolution from the establishment of a new plot of 10 homogenous young plants to the flowering of these 10 plants (all these plants should be changed at the same time just before flowering). The evolution of the YLS on a same banana plant is a balance between the rate of necrotic formation and the foliar emission rate. Thus, the evolution of this parameter is helpful to understand the efficiency of the fungicide control at the level of necrotic formation (i.e., at a lower level than SED and YLSt) : (i) if the value of YLS decreases, the chemical control is failing because necrotic formation is faster than leaf emission; (ii) if the YLS is increasing, so we can conclude that the chemical strategy is efficient to slow down the necrotic formation (Fig. 4). 
- The 'Number of Functional Leaves at Harvest' (NLH) is a final estimator of the effectiveness of the control strategy and a potential indicator of fruit exportability. It is often considered that a functional leaf should have less than $30 \%$ of necrotic surface, although no scientific data support this consideration. Banana companies generally use an empiric threshold of NLH (3-5 according to the companies) in order to decide which bunches are exportable or not. As no reliable experimental data is supporting this assumption the value of NLH should be regarded mostly as an indicator of the efficiency of the chemical strategy at the harvest stage.

Box 3. The Stage of Evolution of the BLSD - SEDb (Fouré \&Ganry, 2008)

Its purpose is to get a biological descriptor of the speed of evolution of the disease, according to climatic conditions and inoculums pressure. It is adapted to the forecast as it is based on the earliest visible detection of infection. It is similar to SEDs for Sigatoka disease, but with some significant modifications due to the virulence of the disease in terms of evolution rate and streaks/spots density

Observation plots are designed to weekly check 10 to 30 homogenous banana plants in their vegetative phase between 5 to 18 leaves (always the same). The observation is qualitative and quantitative consisting of a checking of the youngest leaves (range 2 to 4 ) every week, and scoring the most advanced stage of the disease according both to Brun and Fouré's scales (Brun, 1963; Fouré, 1982c) The checking of the youngest leaves (from I to V) integrates the cigar development (score from $\mathrm{A}$ to $\mathrm{E}$ ) and provides the weekly foliar emission rate

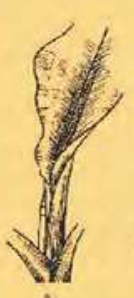

A

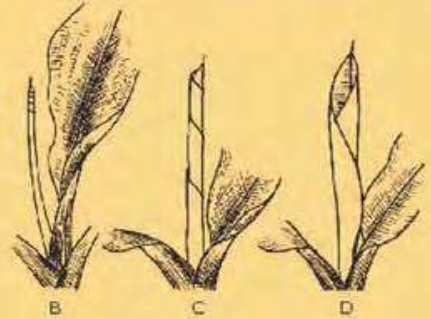

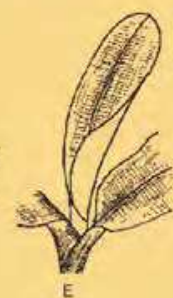

The scoring of the diseases is as follow:

1.Stage 1: a spot is just visible to the naked eye as a minute yellowish-green speck less than $1 \mathrm{~mm}$, only at the underside of the leaf.

2.Stage 2: red or brown streaks (rust colored) are visible firstly on the underside of the leaf, then on both sides. These streaks become progressively brown on the underside and black on the upper side of the leaf. The first outward sign of this stage 2 on the upper side of the leaf is a yellow streak which becomes progressively brown.

3.Stage 3: widening and extension of the stage 2 .

4.Stage 4: this is the spot stage. The spot takes a circular or elliptical form.

5.Stage 5: this corresponds to the first of the two necrotic stages; a yellow halo firstly surrounds a black spot. 6.Stage 6: this corresponds to the second necrotic stage; drying out of the centre of the spot is observed, spots progressively take a grey color, but keep a black halo also surrounded by yellow.

The couple leaf range/ disease stage provides a coefficient that reflects the speed of evolution of the disease:

\begin{tabular}{|c|c|c|c|c|}
\hline \multirow{2}{*}{$\begin{array}{l}\text { Stage of the } \\
\text { disease }^{1}\end{array}$} & \multirow{2}{*}{$\begin{array}{l}\text { Density } \\
\text { of } \\
\text { lesions }\end{array}$} & \multicolumn{3}{|c|}{ Leaf range } \\
\hline & & II & III & IV \\
\hline \multirow[t]{2}{*}{1} & - & 60 & 40 & 20 \\
\hline & + & 100 & 80 & 60 \\
\hline \multirow[t]{2}{*}{2} & - & 100 & 80 & 60 \\
\hline & + & 140 & 120 & 100 \\
\hline \multirow[t]{2}{*}{3} & - & 140 & 120 & 100 \\
\hline & + & 180 & 160 & 140 \\
\hline \multirow[t]{2}{*}{4} & - & 180 & 160 & 140 \\
\hline & + & 220 & 200 & 180 \\
\hline \multirow[t]{2}{*}{5} & - & 220 & 200 & 180 \\
\hline & + & 260 & 240 & 220 \\
\hline \multirow[t]{2}{*}{6} & - & 260 & 240 & 220 \\
\hline & + & 300 & 280 & 260 \\
\hline
\end{tabular}

1 For each stage of the disease, the mark attributed depends on density of lesions, which is estimated by "-" if there are less than 50 outward signs and by " + " if there are more than 50 outward signs. 


\begin{tabular}{|c|c|c|c|c|c|c|c|c|c|c|c|}
\hline \multirow{2}{*}{$\begin{array}{l}\text { Banana tree } \\
\text { number } \\
\text { (BTN) }\end{array}$} & \multirow{2}{*}{$\begin{array}{l}\text { Old leaf } \\
\text { number } \\
\text { (OLN) }\end{array}$} & \multirow{2}{*}{$\begin{array}{l}\text { Old cigar } \\
\text { stage } \\
\text { (OCS) }\end{array}$} & \multirow{2}{*}{$\begin{array}{l}\text { New leaf } \\
\text { number } \\
\text { (NLN) }\end{array}$} & \multirow{2}{*}{$\begin{array}{l}\text { New cigar } \\
\text { stage } \\
\text { (NCS) }\end{array}$} & \multirow[t]{2}{*}{ FER } & \multicolumn{2}{|c|}{ Leaf 2} & \multicolumn{2}{|c|}{ Leaf 3} & \multicolumn{2}{|c|}{ Leaf 4} \\
\hline & & & & & & $\begin{array}{c}\text { Stage } \\
\text { of disease }\end{array}$ & $\begin{array}{l}\text { Lesion } \\
\text { density }\end{array}$ & $\begin{array}{c}\text { Stage } \\
\text { of disease }\end{array}$ & $\begin{array}{l}\text { Lesion } \\
\text { density }\end{array}$ & $\begin{array}{c}\text { Stage } \\
\text { of disease }\end{array}$ & $\begin{array}{l}\text { Lesion } \\
\text { density }\end{array}$ \\
\hline 1 & 14 & 2 & 15 & 0 & 0.8 & None & None & 2 & - & 5 & + \\
\hline 2 & 13 & 6 & 14 & 4 & 0.8 & None & None & 1 & - & 2 & - \\
\hline 3 & 14 & 0 & 15 & 0 & 1 & None & None & 1 & - & 2 & - \\
\hline 4 & 13 & 6 & 14 & 4 & 0.8 & None & None & 2 & - & 2 & - \\
\hline 5 & 15 & 8 & 16 & 6 & 0.8 & None & None & 1 & - & 1 & - \\
\hline 6 & 15 & 2 & 16 & 2 & 1 & None & None & 1 & - & 1 & - \\
\hline 7 & 14 & 0 & 14 & 8 & 0.8 & None & None & 2 & - & 1 & - \\
\hline 8 & 15 & 4 & 16 & 4 & 1 & None & None & 2 & - & 3 & - \\
\hline 9 & 14 & 2 & 15 & 0 & 0.8 & None & None & 1 & - & 2 & + \\
\hline 10 & 13 & 6 & 14 & 2 & 0.6 & None & None & 1 & - & 1 & + \\
\hline
\end{tabular}

\begin{tabular}{|c|c|c|c|c|c|c|c|c|c|}
\hline \multirow{3}{*}{$\begin{array}{l}\text { Stage of the } \\
\text { disease }\end{array}$} & \multicolumn{6}{|c|}{ Number of stage observation coupled with lesion density in leaves } & \multicolumn{3}{|c|}{ Coefficient attributed to the stage } \\
\hline & \multicolumn{2}{|c|}{ Leaf 2} & \multicolumn{2}{|c|}{ Leaf 3} & \multicolumn{2}{|c|}{ Leaf 4} & \multirow[t]{2}{*}{ Leaf 2} & \multirow[t]{2}{*}{ Leaf 3} & \multirow[t]{2}{*}{ Leaf 4} \\
\hline & $\begin{array}{l}\text { Frequency of } \\
\text { disease stage }\end{array}$ & Lesion density & $\begin{array}{l}\text { Frequency of } \\
\text { disease stage }\end{array}$ & Lesion density & $\begin{array}{l}\text { Frequency of } \\
\text { disease stage }\end{array}$ & Lesion density & & & \\
\hline 1 & None & None & 6 & - & $\begin{array}{l}3 \\
1\end{array}$ & $\overline{+}$ & None & 240 & $\begin{array}{l}60 \\
60\end{array}$ \\
\hline 2 & None & None & 4 & - & $\begin{array}{l}3 \\
1\end{array}$ & + & None & 320 & $\begin{array}{l}160 \\
100\end{array}$ \\
\hline 3 & None & None & None & None & 1 & - & None & None & 100 \\
\hline 4 & None & None & None & None & None & None & None & None & None \\
\hline 5 & None & None & None & None & 1 & + & None & None & 220 \\
\hline 6 & None & None & None & None & None & None & None & None & None \\
\hline Sum $_{\text {coest }}$ per & eased leaf & & & & & & & 560 & 720 \\
\hline
\end{tabular}

\begin{tabular}{|c|c|c|c|c|c|}
\hline (c) Calcul & $n$ of weekly $F$ & & & & \\
\hline SUM $_{\text {FER }}$ & Numberdays & $\mathrm{FER}_{10 \mathrm{~d}}$ & $\mathrm{FER}_{\text {past wak }}$ & $\mathrm{FER}_{\text {new week }}$ & Sum $_{\text {coet }}$ \\
\hline 8.4 & 7 & 1.2 & 1.3 & 1.25 & 1280 \\
\hline
\end{tabular}

(d) Calculation of weekly SED: Sum coet $\times \mathrm{FER}_{\text {new week }}=1600$.

Table 2. Example of a data sheet used for the calculation of the weekly SEDb in banana plants (FER = Foliar Emission Rate) ( from Fouré EGanry, 2008)

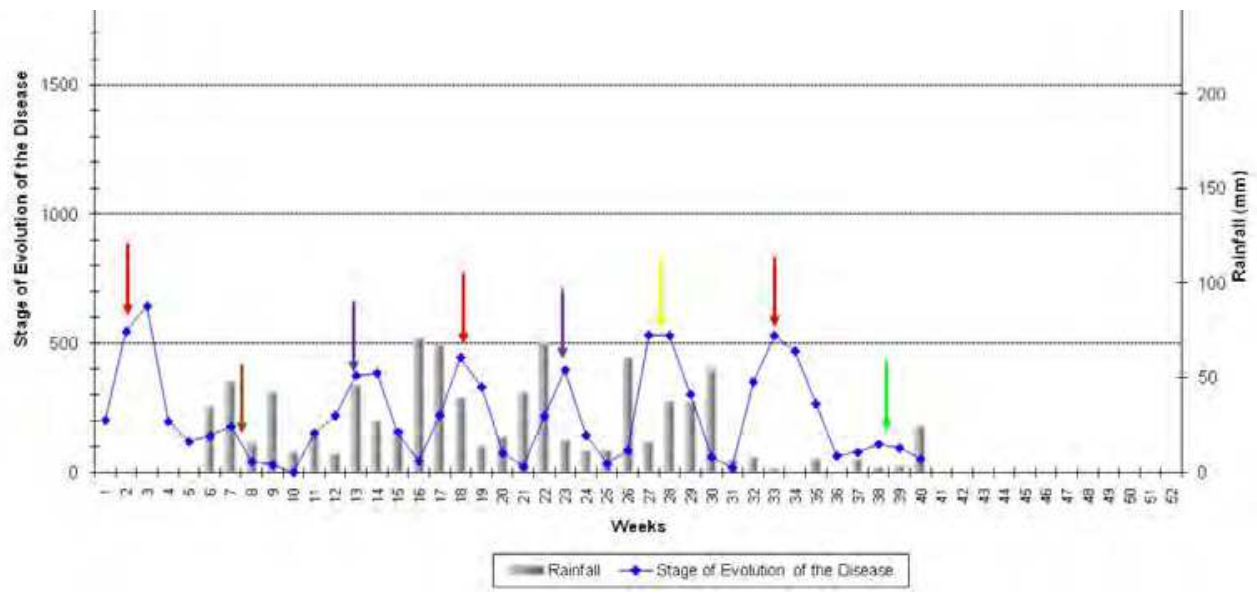

Fig. 3. Illustration of the Stage of Evolution of Disease's (SEDb) potential to forecast fungicide applications and to monitor the efficiency of the chemical control strategy in banana plantations. All fungicide applications are indicated by an arrow above the SEDb curve (arrows with different colors correspond to different fungicides applied) (from de Lapeyre de Bellaire et al., 2010a) 


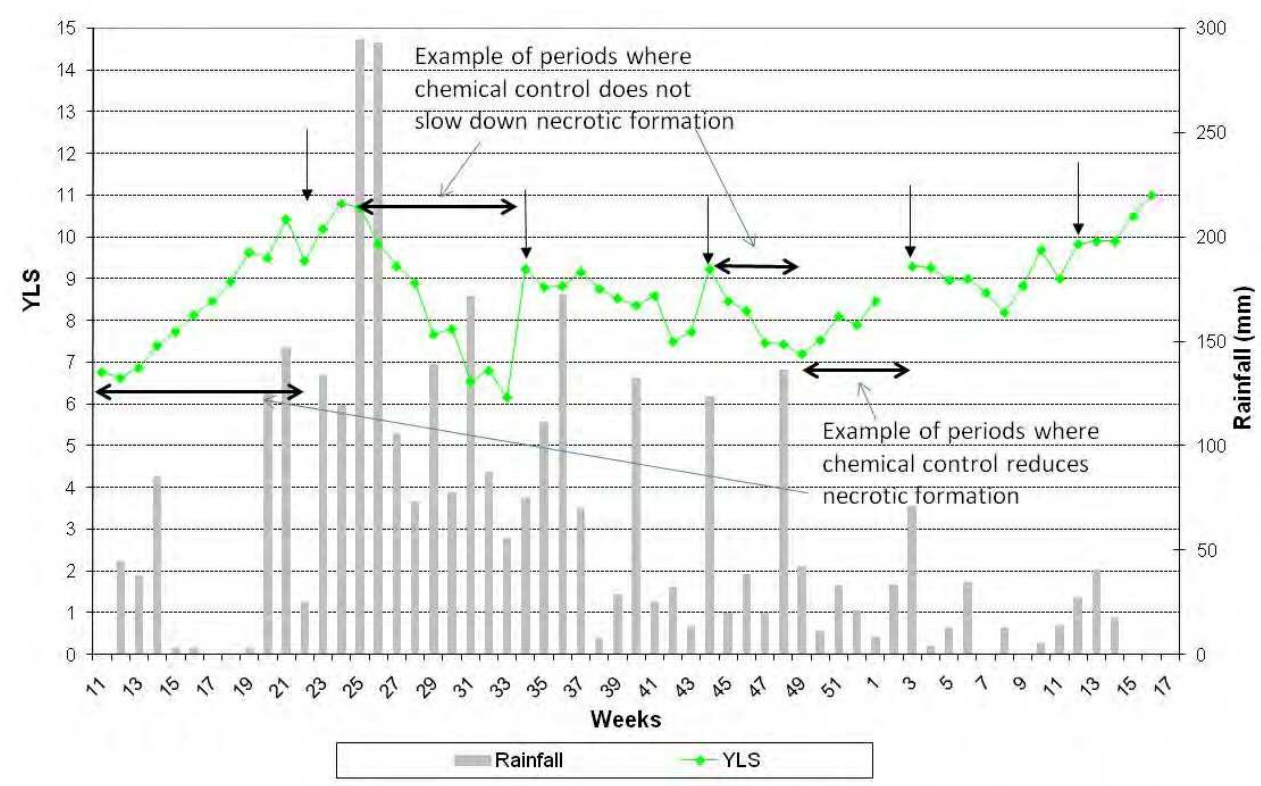

Fig. 4. Illustration of interpretation of the Youngest Leaf Spotted (YLS) from its weekly evolution in banana plantations. Arrows indicate the date at which the whole 10 banana plants where changed At that date, the variation should not be considered as the value of YLS is artificially different. YLS is scored according to Stover's method (from de Lapeyre de Bellaire et al., 2010a)

\subsubsection{Component 2: Timing and quality of the fungicide applications}

The timing of the fungicide applications is driven by SEDb and the analysis of other parameters. It is the reason why it must be implemented by highly skilled teams.

The time between decision and execution of one application should not exceed 2 days. Sprays are carried out by airplane, helicopter, or by backpack sprayer on small surfaces. However, care must be taken with the climatic conditions of aerial spraying: only a small window, early in the morning and late in the afternoon, is suitable; otherwise, thermal inversion and air turbulence do not allow correct spray deposition. Aerial application is not possible on rainy and windy days. Logistics available is therefore essential to optimize spraying during this small window.

The efficiency of sprays is dependent on the quality of the foliar application, and a good coverage is essential.

The weather conditions the day of application are critical: temperature must be rather cool (less than $28^{\circ} \mathrm{C}$ ) and wind as low as possible $\left(<1.3 \mathrm{~m} . \mathrm{s}^{-1}\right)$ and regular. Sprayers and nozzles must be cleaned every day and calibrated frequently (calibration depends on the use of water or oil and on the rate of mixture used per ha). Significant technical improvement has been achieved when aircraft are guided precisely by GPS. 
An irregular topography of the zone or the presence of obstacles might alter the uniformity of the treatment. The banana plots must be shaped to facilitate aerial sprays, taking into account the presence of obstacles and wind drift, and the crop density should not be too high to allow good penetration of the fungicide spray. A strong synergy between the aerial spraying companies and the banana growers is also important to ensure the quality of the aerial applications.

The use of mineral oils as a carrier considerably improves the quality of coverage through aerial spraying with low volumes (12-15 L ha-1). The quality of oil is essential and must fit with the norms defined by Cuille and Blanchet in 1958 and always used. The quality of the mix with the fungicide is important as well. Fungicides must be used at full rate in order to limit the risk of fungicide resistance.

\begin{tabular}{|c|c|}
\hline Characteristics & norms \\
\hline Viscosity & 4 à $7^{\circ}$ Engler at $20^{\circ} \mathrm{C}$ \\
\hline Density & 0.83 to 0.90 \\
\hline Sulfonation index & $85-90 \%$ maximum \\
\hline Type & indifferently paraffinic or naphtenic \\
\hline Acidity & less than 0.16 \\
\hline Addition ingredients & no sulfur compound \\
\hline
\end{tabular}

Table 3. Characteristics of oil used for sprays in the control of SLSD (Cuillé \& Blanchet, 1958)

The efficiency of treatments relies on a strong curative effect. Thus, systemic fungicides (antimitotics, sterol inhibitors of group 1 and 2, strobilurines, pyrimidins) are preferred to contact fungicides (see Box 4).

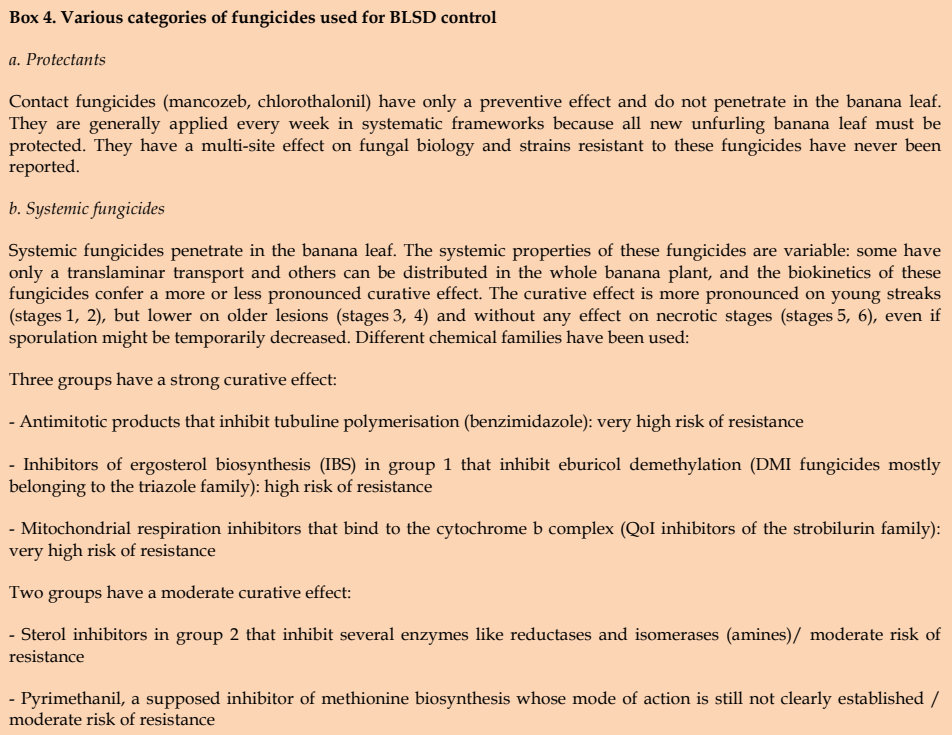

Systemic fungicides penetrate in the banana leaf. The systemic properties of these fungicides are variable: some have only a translaminar transport and others can be distributed in the whole banana plant, and the biokinetics of these fungicides confer a more or less pronounced curative effect. The curative effect is more pronounced on young streaks (stages 1, 2), but lower on older lesions (stages 3,4) and without any effect on necrotic stages (stages 5, 6), even if sporulation might be temporarily decreased. Different chemical families have been used:

Three groups have a strong curative effect:

- Antimitotic products that inhibit tubuline polymerisation (benzimidazole): very high risk of resistance

- Inhibitors of ergosterol biosynthesis (IBS) in group 1 that inhibit eburicol demethylation (DMI fungicides mostly belonging to the triazole family): high risk of resistance

- Mitochondrial respiration inhibitors that bind to the cytochrome b complex (QoI inhibitors of the strobilurin family): very high risk of resistance

Two groups have a moderate curative effect:

- Sterol inhibitors in group 2 that inhibit several enzymes like reductases and isomerases (amines)/ moderate risk of resistance

- Pyrimethanil, a supposed inhibitor of methionine biosynthesis whose mode of action is still not clearly established / moderate risk of resistance 
The use of these fungicides in pure oil strengthens their curative effect, because mineral oils are fungistatic. Attention should be paid to the formulation of the fungicide used. Only formulations compatible with pure oil should be used. Phytotoxic effects of the oil have to be preliminarily determined. Fungicide concentration must also be determined according to preliminary field experiments.

\subsubsection{Component 3: The control of the inoculum pressure in the field}

It is achieved through prophylactic leaf removal coupled with relevant crop management, such as plant density and water and fertilizer management.

The experience of BLSD control in Gabon (see \$2.2) has clearly shown that when plantain fields were isolated into a forest environment and far from infected plots, preventing them from external contamination, the disease control was strongly facilitated.

Thus, keeping the sources of inoculum at a very low level is very important to ensure the success of the chemical control strategy. Where extensive spotting is present, new infections will develop quickly because chemical sprays do not remove the disease from spotted leaves and the only solution is to remove them mechanically from the banana tree. Therefore, such necrotic leaf removal must be a regular practice in banana growing countries where BLSD is present. It should be based on a risk management approach, taking into account that it could affect the production beyond certain level.

Experimental leaf removal has shown that bunch weight, the main yield component, is poorly affected as long as 5 to 7 leaves remain on the plant from flowering to harvest (Ramsey et al., 1990; Daniells et al., 1994; Vargas et al., 2009). A stronger leaf removal could affect the final yield. In addition a lack of resources during this phase, due to severe spotting could compromise the yield of the next ratoon (Eckstein et al., 1995; Dens et al., 2008).

Leaf removal is particularly needed in critical areas where regular sprays are not well performed due to natural obstacles or to regulatory measures such as in buffer areas where aerial spraying is prohibited (e.g. $50 \mathrm{~m}$ from houses, gardens, rivers and roads in the FWI). A strong communication effort should be done towards the farm managers in order to improve the situation, because the chemical control strategy will not be successful if the leaf removal is not done properly. Such leaf removal might be mandatory on BLSD susceptible banana plants that cannot be part of the spraying agenda: in home gardens, near houses, along roads or rivers. In such situations the best solution would be to replace the susceptible bananas by resistant varieties. It requires to take into account social and political components, such as the acceptability of these varieties by the consumers in order to encourage voluntary behavior. In some cases like in Australia, more coercive measures were used with an objective of complete eradication which was successfully achieved (Henderson et al., 2006).

In addition it is essential to destroy systematically all abandoned plantations and isolated roadside banana plants that are potential reservoir of disease inoculums.

In areas where fungicide sprays are done, it is essential to realize necrotic leaf removal before any fungicide spray in order to lower the inoculum pressure and thus enhance the efficiency of the fungicide and to minimize the exposure of the pathogen to the fungicide and thus the risk of appearance of resistant strains to the fungicide. 
Box 5a - Technical Sheet used in the FWI for the mechanical sanitation of banana for the Leaf Spot Diseases control

(part 1)

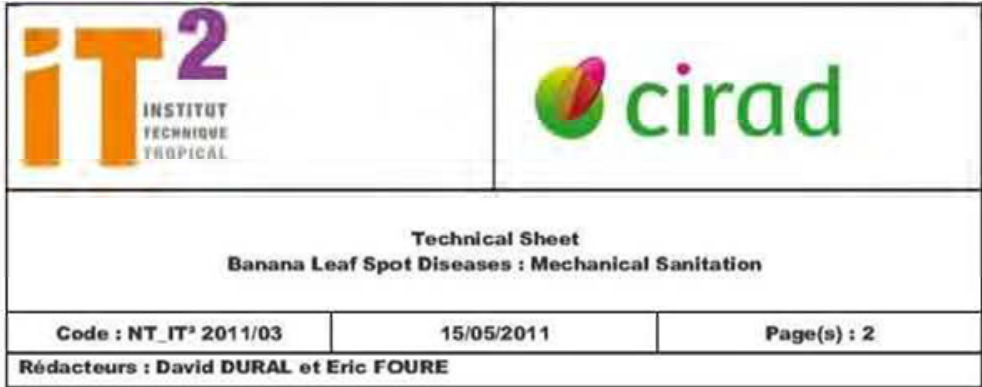

SANITARY LEAF REMOVAL = removal of leaves showing necrosis and symptoms that may move rapidly into necrosis

- SANITARY LEAF REMOVAL is a priority cultural practice that is mandatory accompanying chemical control.

- SANITARY LEAF REMOVAL is fully part of the disease control as it can signiffearity reduce the amount of inoculum present in plantations.

- SANITARY LEAF REMOVAl should be performed regularly to prevent further necrosis appearance on the leaves. In this respect spots that cannot be blocked by the fungicide sprays must be withdrawn.

It is therefore essential to be familiar with different symptoms and stages of the disease to achieve the proper leaf removal.

\begin{tabular}{|c|c|c|}
\hline Stages of the disease & $\begin{array}{l}\text { Sigatoka Leaf Spot Disease } \\
\text { (SLSD) } \\
\text { or Yellow Sigatoka }\end{array}$ & $\begin{array}{l}\text { Black Leaf Streak Disease } \\
\text { (BLSD) } \\
\text { or Black Sigatoka }\end{array}$ \\
\hline Stage 1 & Yellow spot $<1 \mathrm{~mm}$ & $\begin{array}{l}\text { Yellowish depigmentation } \\
\text { spot }\end{array}$ \\
\hline Stagen 2 & Yellow streak 1 to $5 \mathrm{~mm}$ & $\begin{array}{l}\text { Extension of the fesion- } \\
\text { Brown streaks }\end{array}$ \\
\hline $\begin{array}{c}\text { Stage } 3 \text { Contamination } \\
\text { (conidia) }\end{array}$ & $\begin{array}{l}\text { Enlargement of the streah } \\
\text { takes a rusty color }\end{array}$ & $\begin{array}{l}\text { Elongation and enlargement } \\
\text { of the lesion visible on the } \\
\text { under and upper sides }\end{array}$ \\
\hline $\begin{array}{c}\text { Stage } 4 \text { Contaminatien } \\
\text { (conlafia) }\end{array}$ & Brown losion with a yello & Brown oval lesion \\
\hline $\begin{array}{l}\text { Stage } 5 \text { r necrosis } \\
\text { Contaminatlon } \\
\text { (ascosperea) }\end{array}$ & Necrotic lesion with gray & Black lesion \\
\hline $\begin{array}{l}\text { Stage } 6 \text { : nocrosis } \\
\text { Contamination } \\
\text { (ascosperes) }\end{array}$ & No stage 6 & $\begin{array}{l}\text { Necrotic lesion with gray } \\
\text { color-yellow halo for } \\
\text { Isolated lesion }\end{array}$ \\
\hline
\end{tabular}


Box $\mathbf{5 b}$ - Technical Sheet used in the FWI for the mechanical sanitation of banana for the Leaf Spot Diseases control

(part 2)

SANITARY LEAF REMOVAL must be completed before the chemical spray (no fungicide spray on necrosis / risk of resistance emergence).

SANITARY LEAF REMOVAL increases the efficiency and sustainability of the current chemical control strategies.

Black Sigatoka: the presence on the leaves of stages 3 and 4 may result in a few days in the emergence of new necrotic stages 5 and 6 . These symptoms of stage 3 and 4 cannot be blocked by fungicide sprays.

This requires that SANITARY LEAF REMOVAL is performed as soon as stages 3 and 4 are detected.

\section{TERMS OF THE LEAF REMOVAL:}

$50 \%$ of the leaf area must be removed if stages $3-4$ and / or $5-6$ (BLSD) and / or $4-5$ (SLSD) are present only on this half leaf. The leaf will be cut (total removal) if the symptoms are present throughout the leaf area

In some cases and in some producing plots, a severe sanitation can lead to the removal of most of the leaves present on the banana when it is the only way to rapidly and permanently clean the related plots

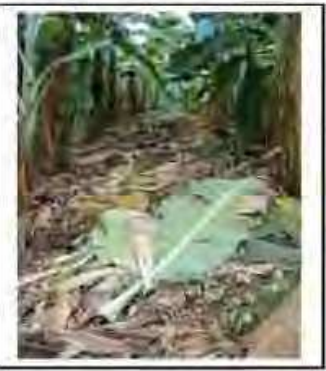

The cutted leaves with necrosis will be returned with the upper side against the ground to limit the spread of ascospores.

In the first cycle, it is recommended to put the cutted leaves in a pile at the end of the row(in this case, only the sheet placed on top is likely to emit spores).

A spotted leaf left hanging along the pseudostem produces spores for about 4 to 5 months against 2 to 3 weeks if it is on the ground.

A SANITARY LEAF REMOVAL correctly and regularly done reduces the production of spores of more than $\mathbf{8 0} \%$; thus it must be considered as a priority control practice

The achievement of this sanitary leaf removal by ALL. THE GROWERS is a key element of the success in the control of black Sigatoka; IT IS OUR PRIORITV?

Other measures for the control of Black Sigatoka:

- Elimination of all isolated banana plants that may be on the edge of the plot; they are sources of contamination.

- Regular desuckering to avoid the ratoon bunches in the field as they are also sources of contamination.

- Rapid switch to fallow by injecting glyphosate and rapid burial ( 2 weeks after injection) in order to avoid necrosis of the leaves on the plants that will remain a source of contamination for a long time and to avoid regrowth. 


\subsubsection{Component 4: The fungicide sequence management}

The forecasting strategies enable BLSD control with a limited use of fungicides. In such strategies, the cost of control is lower but, above all, the environmental impact is limited.

Such strategies should be preferred to systematic strategies that are conducive to significant environmental impact and they should be combined with other measures such as sanitation (leaf removal), drainage, under-cover irrigation and good fertilization practices. Forecasting strategies have faced some drawbacks in some countries, especially in Cameroon, because of the emergence of fungicide resistance to systemic fungicides. It is the reason why such strategies should be implemented under specific conditions in the related banana industry: (i) banana areas with no or few fungicide resistance to available fungicide families and particularly those where adverse climatic conditions exist during a part of the year (dry season). This is still the case in some parts of Ivory Coast, Ghana and the Caribbean; (ii) availability of curative fungicides with different mode of actions that can be used in alternation and offering alternatives in case of fungicide resistance is detected in one family; (iii) logistic capacity to operate when necessary without any delay and in the best conditions (window); (iv) strong involvement of the plantation managers and cooperation of the citizens and administration to contribute to the sanitation of banana plants (see \$1.4).

When new plantations are established in new areas of a country where fungicide resistance is present, special attention should be paid to germplasm movement in order to prevent the introduction of resistant strains through planting material. Nurseries for planting material must be established in areas where the presence of resistant strains has not been demonstrated. This is, for instance, the case in Cameroon and Ivory Coast. In such situations, the sustainability of the forecasting strategy would be a significant challenge.

It is clear that a key component of a good fungicide sequence management relies on a regular monitoring of fungal populations (see box 6).

A special attention should be paid to the management of fungicide resistance that might develop following the repetitive use of curative fungicides that have a monosite action. Alternation between different groups of fungicides, or mixtures with contact fungicides, is essential to reduce selection pressure and delay the emergence of such resistance.

In several countries where such attention was not so high, the regular and intensive use of systemic fungicides has resulted in an important development of resistant strains in Mycosphaerella fijiensis populations. These data are well documented inside the banana working group of FRAC (Fungicide Resistance Action Committee). The resistance risk is considered as severe for strobilurins and antimitotics, and important for IBS of group 1.

The current status of fungicide resistance to these chemicals is a key information to monitor control strategies for BLSD based on a forecasting strategy because these strategies rely on the use of fungicides having a strong curative effect, i.e. systemic fungicides. It is also important to note that the cost of systemic fungicides is higher than the protectants, and that their use is then justified if they really enable a good control of BLSD with a lower number of applications.

It is the reason why a regular resistance monitoring is of prime importance in an integrated disease management system for BLSD (box 6) 
Box 6. Resistance monitoring: The basic methodology relies on the comparison of the sensitivity to the different fungicides in fungal populations (50-100 spores) sampled in commercial farms (treated with the fungicides) and fungal populations sampled in untreated locations. The monitoring of sensitivity is based on germination tests: the germination of spores grown on agar media added with different concentrations of fungicides is compared with the germination of spores grown on agar (de Lapeyre de Bellaire et al., 2010b).

- For benzimidazoles, susceptible strains do not germinate on agar added with the fungicide or have distorted germtubes. Resistant strains have a normal or short germtube as compared with the control on ager medium.

- For sterol inhibitors, the germ tube length is measured and the \% of growth inhibition (GI) is calculated for each strain at a specific concentration. The distribution of the GI in the population sampled in the treated farm is then compared to the distribution of the population sampled in the untreated farm. Another possibility is to evaluate the EC50 concentration (concentration for $50 \%$ GI) for each strain from GI assessed over a large range of concentration of the target fungicide.

- $\quad$ For strobilurines, the germ tube length is measured and the \% of growth inhibition (GI) is calculated for each strain at a specific concentration. A strain is considered as resistant if germ tube length or GI is over a threshold value.

In the methodology approved by the FRAC (see FRAC website, monitoring methods (MYCOFI)), fungal populations consist in ascospores obtained from necrotic leaf samples (20-25 plants are sampled in each location). At laboratory, these necrotic leaf samples are bulked and incubated in a moist chamber for $48 \mathrm{~h}$ and then leaf pieces are used for ascospore discharge on petri dishes enriched with the targeted fungicide.

This method has several drawbacks : (i) ascospore production is very fluctuable and the population analyzed in the Petri dishes might be very different from the population initially sampled in the field; (ii) in certain cases sporulation does not occur and the test cannot be carried, especially in the dry season; (iii) this method does not allow to use a predetermined sampling design; (iv) the populations analysed on each fungicide concentration and the control are always different; (v) other ascospores belonging to the genus Mycosphaerella might be confused with the ascospores of M. fijiensis, especially on fungicide amended media.

Then new methods are presently developed from conidia to overcome these drawbacks.

\subsubsection{Component 5: Organization of the control}

The success story of SLSD control in Guadeloupe and Martinique is particularly due to the mode of organization.

Centralization of decisions and operations is essential and the banana growers should be grouped in an association that would perform the control strategy. 
Since ascospores are transported by wind over long distances, the control strategy should be the same in all banana plantations to prevent any disruption. The organization of the treatments is more efficient when a centralization of the decision is performed by a unique technical service operating according to rational guidelines rather than if each grower implements his own strategy.

\subsection{BLSD control in Cameroon in the banana industry for export}

In Cameroon, M. fijiensis was first reported in 1981. In the late 80s, a warning method using biological descriptors has been developed based on the strong experience gained with the control of SLSD in the FWI (Ganry \& Laville, 1983; Bureau \& Ganry, 1987; Bureau et al., 1982) and on results obtained in Gabon with BLSD on plantain (Fouré 1982a, 1982b, 1983, 1984, 1985; Fouré \& Grisoni, 1984, Fouré et al., 1984). It was successfully applied, thus limiting the number of applications to 12-14 per year. This rational control by warning relied heavily on the use of systemic fungicides with a high curative effect (Fouré, 1988a, 1988b, 1988c; Fouré \& Mouliom Pefoura, 1988; Fouré \& Moreau, 1992).

This situation was sustainable for 10 years, but disease control then became unsuccessful due to logistic failures (shortage of airplanes), which led to the more intensive use of systemic fungicides.

As a consequence, since 1996 the emergence of strains resistant to systemic fungicides resulted in the progressive replacement of this rational control strategy by more frequent applications of systemic fungicides. As a result, resistance to site-specific strobilurins has developed particularly swiftly. Systemic fungicides have been progressively abandoned and replaced by contact fungicides, with chlorothalonil the most frequently used (Fig. 4). The contact fungicides do not cause the emergence of resistant strains, but have not the curative effect required for a prolonged action, as in the case of systemic's.

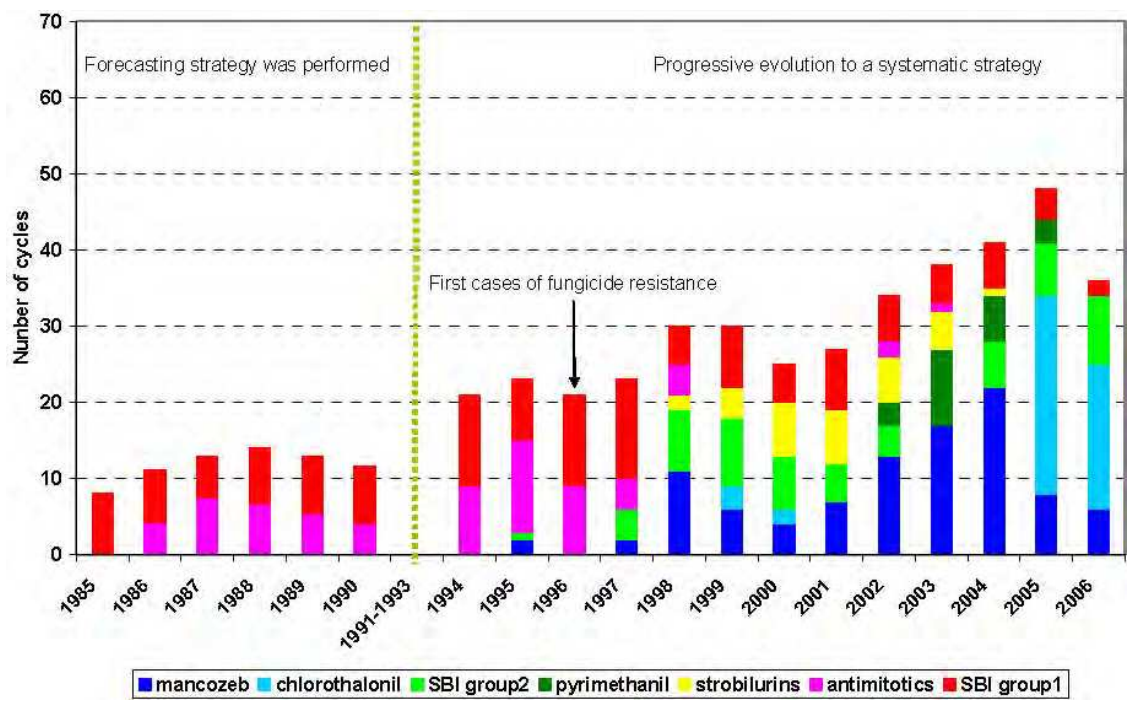

Fig. 5. History of fungicide use for BLSD control in a representative commercial banana farm in Cameroon from 1985 to 2006 (de Lapeyre de Bellaire et al., 2009). 
Thus, in 2006, despite a continuing effort to drive the chemical control from the observation of biological descriptors, about 40 treatments were performed on most plantations. This increase in the number of treatments resulted in an increase in the cost of the control, but also in environmental risks, as contact fungicides are applied at higher rates than systemic fungicides (de Lapeyre de Bellaire et al., 2009). So, this evolution has led to an important increase of negative environmental effects since 30-40 kg/a.i/ha/year are now applied (vs. $2-4 \mathrm{~kg} / \mathrm{ha}$ /year in the former forecasting system)

Recent observations of the latest monitoring show there is a decrease in resistance levels in some commercial plantations, especially since the systemic fungicides are no longer or rarely used (de Lapeyre de Bellaire et al., 2010b)

This trend suggests that the phenomena of resistance to fungicides may be reversible (see Box 7 and 8 ) and thus that new treatment strategies can be redefined in a more sustainable both economic and environmental - way.

In the horizon of 2 or 3 years, it seems possible to recover one or two fungicides and reintegrate them with newly available chemical family as part of an integrated strategy that would reduce the number of fungicide applications and the amount of active ingredient spread.

\section{Box 7.}

Resistance to benzimidazoles and strobilurins has actually dropped since they are no longer used. But we still need a background of resistance that can even advise their use. However there is every reason to be optimistic about the possibility of reuse, at the horizon of a few years in some areas under warning strategies that would also benefit the registration of systemic fungicides with new mode of action, like succinate deshydrogenase inhibitors (SDHI) that will be soon released. With regard to the triazoles, the sensitivity deteriorates steadily mainly because they still are used in most plantations. Their use should be postponed in order to recover sensitivity.

\section{Box 8.}

Several mechanisms may be behind this recent drop of resistance levels observed in Cameroon:

- Gene flow from untreated areas (because of the absence of chemical treatments, populations have high size and are susceptible to all fungicides in untreated neighboring plantains), to commercial plantations (because of fungicide applications populations have lower size in commercial treated farms) that could cause a progressive "dilution" of fungicide resistance

- A loss of competitiveness of resistant strains which would be phased out when the fungicide selection pressure is off. Effectively, in some cases and particularly for DMI fungicides, fungicide resistance has a fitness cost (Karaoglanidis et al, 2001)

\subsection{BLSD control in Gabon in small scale plantain production for domestic markets}

Here are briefly presented the activities conducted on the agro-industrial plantation of plantains at N'toum (100 ha, $60 \mathrm{~km}$ from Libreville, Gabon) created in the late 1980s to supply the urban markets of Libreville 
For the first time in Central Africa, the BLSD was detected in this area of Ntoum in 1980 (Frossard, 1980). Given the pathogenic activity of the fungus, a research program was implemented in this country. It was based on the study of certain aspects of the biology and the epidemiology of the causal agent of the BLSD, Mycosphaerella fijiensis and the development of a warning method for a rational chemical control of the disease (Fouré, 1983; 1984, Fouré et al., 1984). Continuous analysis of biological descriptors (observation of various stages and progression of the disease on the foliage) and the use of systemic fungicides has produced very satisfactory results in this intensive plantation of plantain and effectively controlled the BLSD on 100 ha of plantain in Ntoum (ten fungicide sprays / year; alternation of systemic fungicides). One of the reasons why it was possible to reach such good results was related to the situation of these plantain fields which were very isolated into a forest environment, preventing from external contamination.

This program was an important contribution in the adaptation of a biological warning method for BLSD control.

\subsection{BLSD control in the French West Indies}

Up to recently, the French West Indies islands were still free of the BLSD.

The SLSD has been controlled effectively and at lower economic and environmental costs through the implementation of a pest management strategy based on a warning system over more than 30 years (5-7 treatments / year). It has been already described in the $\$ 1$.

Recent developments in the phytosanitary regulations in France (withdrawing of most fungicides and difficulty for registration of new active ingredients) resulted in a sharp decrease of the 'in vitro' susceptibility of the fungicides that are still registered for the control against the SLSD. Thus, the number of treatments performed each year has increased very recently (10-12 treatments per year). In addition, there was also a change in French legislation on aerial spraying and the establishment of untreated buffer zones in a distance of $50 \mathrm{~m}$ from houses, gardens, rivers, roads.... Ultimately, it is possible that the aerial treatments will be prohibited.

Recent developments in the spread of the BLSD in the Greater Antilles and more recently in the Lesser Antilles (Fig. 5) suggested that its arrival in Martinique (and probably a later deadline in Guadeloupe) was inevitable in a more or less short term.

Inexorably, BLSD was detected in Martinique in September 2010 and since then it has spread very fast, making it unfeasible any eradication attempt.

Thus, the unique solution is to apply an integrated disease management approach based on the key principles inherited from the lessons learned with BLSD in other areas, and taking into account the excellent know-how of the banana industry in control of the SLSD through a forecasting system.

The effectiveness of pest management is also based on the common management and centralized mode of organization that is working out in Martinique and Guadeloupe for over 30 years. This type of organization is undeniably a major asset for the successful implementation of this strategy. Nevertheless, the implementation of this strategy might be hampered by the limited number of fungicides registered in the FWI for BLSD control and by the effective regulation of BLSD in the $50 \mathrm{~m}$ buffer areas. 


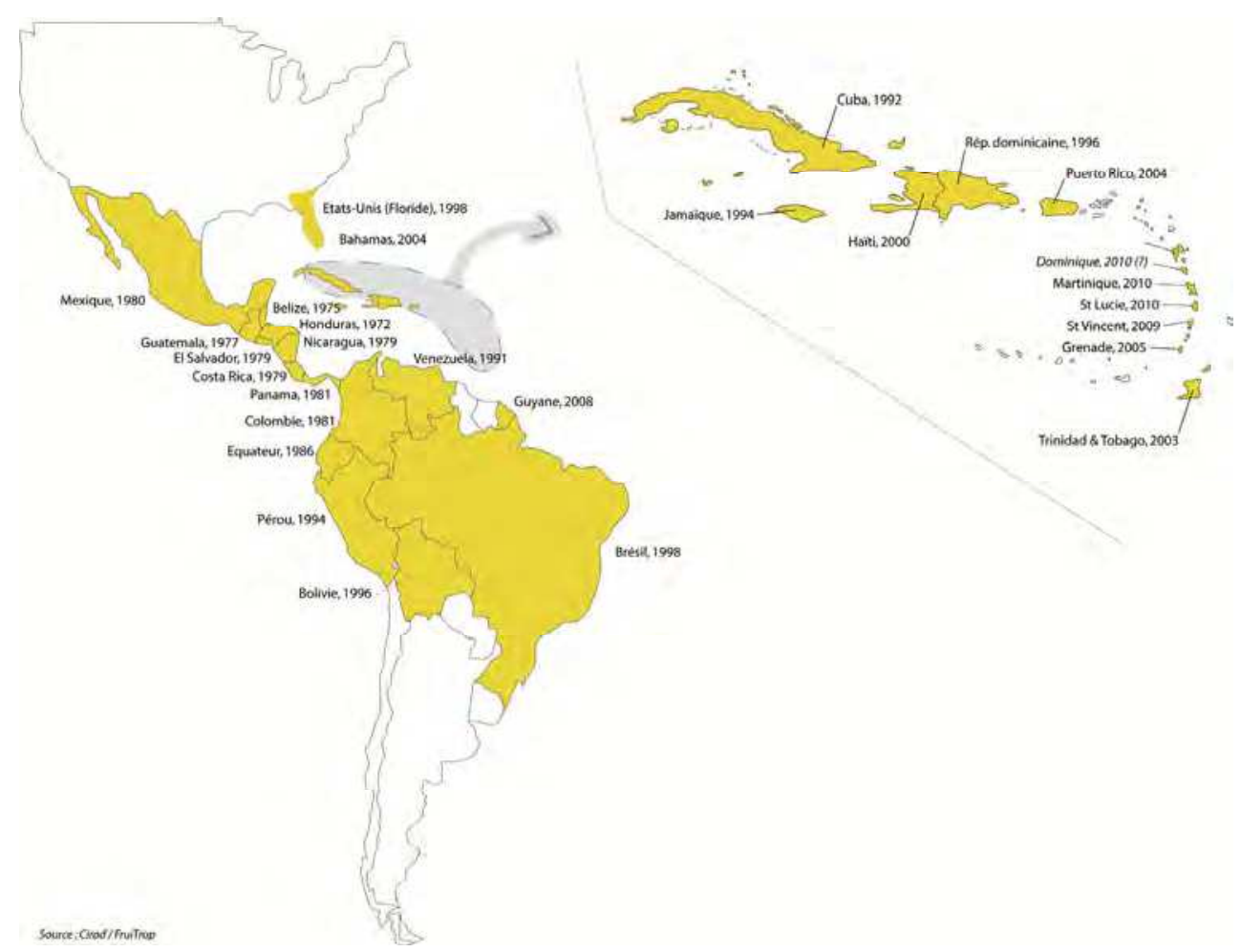

Fig. 6. Geographic expansion of BLSD in the Americas

\subsection{BLSD control in Latin America in the banana industry for export: The case of Belize}

The forecasting system described in previous chapters, has been adapted and implemented in several countries in Latin America (Marin, 2003). In some situations in Central America, the commercial adaptation of the early warning system resulted in a significant reduction in the number of fungicide applications. However, due to various factors related to weather patterns and high resistance levels, there was a "come-back" to systematic sprays with contact fungicides. Some commercial programs still use the system only to help management decisions (Marin, 2003)

In Belize, BLSD is controlled on an area of 2600 Ha through aerial spraying of fungicides. The control of the disease is centrally managed by the Banana Growers Association (BGA). The Sigatoka service of BGA is accountable for the number of cycles, timing of applications and for the type of fungicides used during the campaign for BLSD control on each farm belonging to a same pedo-climatic area. At the beginning of 2006, the Sigatoka service of BGA was in charge of weekly disease assessment in the different farms, based on the evaluation of the youngest leaf with visible streaks from the ground (YLS) and of the total number of functional leaves ( see $\$ 1.1$ ). Some farms had started to implement disease assessments for a biological forecasting (de Lapeyre de Bellaire, 2006 \& 2007). 
The centralization of BLSD control was very suitable for disease management because it guarantees that a same technical guideline is used over the whole banana area. Nevertheless, an indirect negative consequence of this centralization was that banana growers were less involved directly in BLSD, especially for leaf removal.

Three airplanes and two pilots were available for spraying, which is the minimum to control the disease over 2600 ha in order to optimize spraying during the best conditions (small window in the morning).

Fungicides used for BLSD control fall in the 2 categories described earlier: protectants, and systemic fungicides (Box 3).

The spraying program was generally based on the use of contact fungicides during the dry season (February to May) and systemic fungicides being mainly used in the rainy season.

Many fungicides are registered for BLSD control in Belize (Table 3), but despite the intensive use of systemic fungicides in recent years (Fig. 6), control of the disease was not successful at that time, and significant losses were registered (de Lapeyre de Bellaire, 2006). High disease outbreaks resulted in bunch reject, bunch weight losses and strong quality problems linked with early ripening and heterogeneity of ripening in ripening rooms.

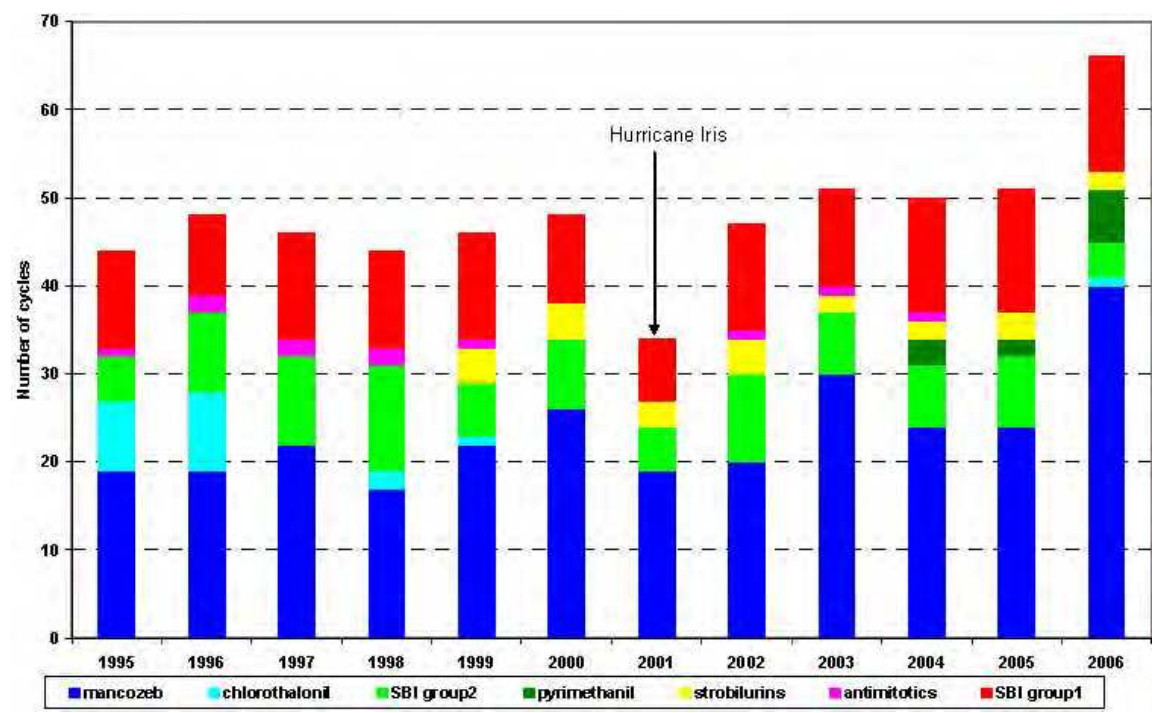

Fig. 7. History of fungicide use for BLSD control in a representative commercial banana farm in Belize (1995-2006) (from de Lapeyre de Bellaire, 2006)

In 2006, a fungicide resistance monitoring campaign was achieved thanks to the contribution of CIRAD's laboratory in Montpellier. The results of this monitoring analysis showed a very worrying situation in terms of fungicide resistance in all the commercial banana farms. For the three chemical groups evaluated (strobilurins, antimitotics and IBS group 1) high levels of resistance have been observed (de Lapeyre de Bellaire, 2006), which explained the poor control obtained with systemic fungicides in this country. 
In such conditions, satisfactory control could be achieved through a systematic use of contact fungicides, such as mancozeb and chlorothalonil. However, this strategy does not reduce the environmental impact since the number of fungicide applications/year remained high (de Lapeyre de Bellaire, 2007).

Nevertheless, as observed in Cameroon, this strategy could create the opportunity for a possible reversion of resistance, especially for IBS of group 1 and give the possibility to implement in the future the biological forecasting system developed by CIRAD in this country.

\subsection{BLSD control in Latin America in plantain production for export: The case of Panama}

In Panama, as in other Central American countries, a very significant decrease in the production of plantains was observed after the emergence of BLSD. The production in this country was divided by three in five years, from 100,910 tons in 1979 to 31,134 tons in 1984 (Diaz, 1986). The effects were very sensitive on the supply of domestic markets as well as on the prices that have almost doubled over this period. In addition all exports, while expanding (661 tons in 1980, 2338 tons in 1982) were stopped due to a very high quality deterioration caused by the disease.

It was therefore considered interesting to use the experience gained with the control of the Sigatoka Disease in banana plantations of the French West Indies (Bureau, 1990).

The warning system has been implemented on two types of production: small farms of 4-5 ha on average, with a low technicality and family labor and medium farms of 10 to 30 hectare with a good technical level, hired labor and more productive.

In the first case the control was done through ground sprays and in the second case by aircraft.

The results were very promising with a very good control of BLSD in both situations with nine applications a year in family farms and 6.5 applications in medium-sized farms. Such promising results have been achieved through a rigorous execution giving its full preventive character to the system. It is interesting to notice that under these conditions, a very good relationship was found between the evaporation Piche and the duration of treatment efficacy. It appears that the aerial sprays are much more efficient than ground sprays

Apart from Panama, the forecasting system was also used on plantain in other countries such as Costa-Rica. In this latter country the forecasting system has been simplified (Marin, 1992) as well as combined with climatic factors to develop a bioclimatic forecasting system for plantain (Jimenez et al., 1995; Lescot et al., 1998)

\section{Lessons drawn from various experiences and perspectives}

Beyond the biological and technical components there are economic, political, logistical, environmental and social issues that are key points to consider in a holistic approach, otherwise leading to unpredictable failures. 
Chemical control of BLSD would not appear sustainable in the long term. In several countries, fungicide resistance to systemic fungicides is increasing, and chemical control using these fungicides is becoming no longer efficient. In such situations, a systematic use of contact fungicides, as shown in the case studies of Belize and Cameroon, needs to be implemented. As a consequence, warning strategies, which could help reduce costs and environmental impact of chemical control, are becoming useless, because of systematic and frequent sprays. As a consequence, fungicides for BLSD control are the most important contribution to the annual amount of pesticide used in all countries were BLSD is present and where favorable conditions prevail (Risède et al., 2010). In the FWI, fungicide resistance is particularly worrying since the SBI of group 1 are the only fungicides approved. The introduction of very restrictive legislation significantly affects the sustainability of chemical control (table 4). More restrictive legislation aimed to further protect human and environmental health may be passed in the future. New solutions are then necessary to guarantee the sustainability of banana cropping systems (de Lapeyre de Bellaire et al., 2009).

\begin{tabular}{|llll|}
\hline Active ingredient group & Belize & Cameroon & Guadeloupe \\
\hline mancozeb & 8 & 7 & 0 \\
chlorothalonil & 2 & 5 & 0 \\
SBI group 2 & 1 & 3 & 0 \\
pyrimidins & 1 & 2 & 0 \\
strobilurins & 2 & 2 & 0 \\
antimitotics & 1 & 1 & 0 \\
SBI group1 & 5 & 7 & 2 \\
\hline
\end{tabular}

Table 4. Number of fungicide products registered in various countries for BLSD or SLSD control in 2006. (from de Lapeyre de Bellaire et al., 2009)

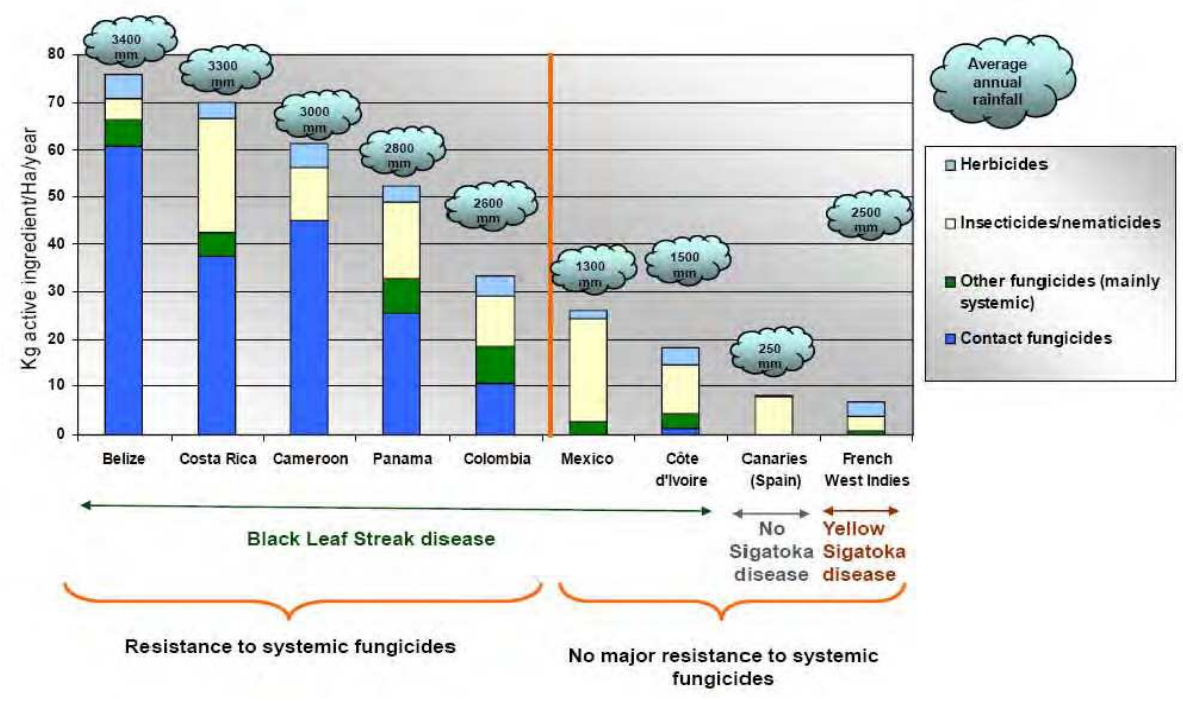

Fig. 8. Estimated total pesticide quantities used by the dessert banana industry in some countries, including European Community areas (2006-2007).C Thierry Lescot, CIRAD, France 


\subsection{Short-term solutions}

The introduction of more eco-friendly fungicides would be beneficial to address environmental and health impact of contacts fungicides. In the past 5 years, organic fungicides or bio-fungicides, such as essential oils, alimentary additives, organic acids, potassium carbonates, leachates of decomposed banana material (bunch stems, fruits), and bio-control agents have been experimented in Cameroon. None of these fungicides gave good control of BLSD under high inoculum pressure. However, recent experimental data suggest that the combination of some bio-control agents (Bacillus subtillis and B. pumilis) applied in mixtures with contact fungicides could enable the reduction of the amount of fungicide applied (de Lapeyre de Bellaire et al., 2009)

In addition, forecasting strategies should be devoted and implemented in areas where specific conditions are fulfilled: (i) areas free of fungicide resistance, (ii) new banana areas, (iii) low disease pressure areas. Where fungicide resistance is established, the reintroduction of forecasting strategies relies on possible fungicide resistance reversion and incoming of new mode of action fungicides with a high curative effect. For instance, in situations where the current fungicide resistance is reversible as shown in Cameroon (see § 2.1), it is possible to carefully reintroduce adequate curative fungicides and thus implement warning strategies.

\subsection{Long-term solutions}

\subsubsection{At the cross-road between genetics and landscape management}

As already mentioned at the beginning, only Cavendish bananas, highly susceptible to BLSD, are grown in the banana industry, which is a high risk for the sustainability of the industry.

For this reason and although the current market organization of the banana industry that is an obstacle to the diversification of banana cultivars in the commodity chain, recourse to resistant varieties in an integrated strategy is certainly part of the future of an integrated BLSD control.

Resistant banana, edible or wild, already exist and two types of resistance have been described (Fouré et al., 1990,Beveraggi et al., 1995, , Jones, 2000).

The first one is a high resistance due to a hypersensitive reaction of the host and characterized by the blockage of symptoms at early stages. It is found in cultivars such as Yangambi $\mathrm{km} 5$ (AAA, Ibota) and in various diploids already used in breeding programs as a source of resistance (Paka, AA and some genotypes from the Mlali group and originated from the Comoros archipelago).

The second one is a partial resistance characterized by a slower evolution of disease symptoms as compared with susceptible varieties. This type of resistance is characteristic of cultivars belonging, for example, to the subgroups Pisang Awak (ABB, i.e., Fougamou) and Mysore (AAB).

Since $M$. fijiensis has significant adaptation capacities, already observed in some situations, the type of resistance used should be polygenic instead of monogenic and thus the breeding

\footnotetext{
3 Virulent strains of M. fijiensis were observed on Paka in the Cook Islands (Fullerton \& Olsen, 1995) ${ }^{3}$. These authors consider that these strains are widespread in the Pacific Islands and also mention that they are virulent on Yangambi $\mathrm{km} 5$ which is also considered as highly resistant to BLSD.
} 
strategy must aim at producing partially resistant rather than highly resistant cultivars. As genetically modified bananas are facing consumer resistance and legislation constraints in most importing countries, the more promising way is to look at innovative ways of conventional breeding.

Few programs are currently focusing on the creation of resistant cultivars through such an approach (Abadie et al., 2009).

Some partially resistant hybrids issued from these programs are already tested but their adaptation to an industry exclusively based on Cavendish cultivars is not an easy task. Consumer and market requirements are major constraints, and selection of suitable export cultivars, if at all possible, is a very long process.

The introduction of resistant cultivars into the agro-system could contribute to a decrease in epidemic development of BLSD on spatial scales that remain to be determined, from field to landscape (Ganry, 2004).

\subsubsection{Definition of acceptable disease thresholds}

Instead of only targeting a perfect control of the disease through chemical control, the banana industry would probably have better question the economically acceptable level of disease, and define the disease management accordingly. Acceptable disease thresholds should be determined through the modeling of the effects of BLSD on bunch mass. Such models should rely on a better understanding of disease effect on dry matter accumulation at different phenological stages and on the differential mobilization of resources by the different organs at these different stages. Since banana is a semi-perennial crop, such models should integrate successive crop cycles.

This global approach for BLSD on the various components of yield will enable the optimization of bunch weight according to a fixed stage of harvest (through agronomic practices), and vice versa.

\subsubsection{A more integrated approach based on strategic decision tools}

While data on the cost of BLSD control are generally only focusing on direct costs for fungicides and fungicide applications, it is necessary to take into account other components including direct costs (spraying operations, leaf removal, etc.), but also indirect costs such as (i) disease monitoring, (ii) losses (bunches rejected, weight reduction, quality reduction), and (iii) the cost of environmental measures (de Lapeyre de Bellaire et al., 2009).

It is the reason why it is important to think about reliable tools for strategic decisions is the evaluation of the global economic incidence of BLSD, as there are no existing tools for this purpose. Such information should be collected in databases and specific models should be defined in order to simulate the potential benefit of changes in the industry. Only this global approach should justify changes in the industry.

\section{Conclusion}

The experience gained in the control of the Sigatoka leaf spot diseases, compared to situations of concern observed in Latin America, shows that an integrated approach applied 
on a sufficiently long period, can master the agricultural risk related to the disease and minimize economic impact and environmental damages as well.

The limited use of fungicides through this system is more sustainable than the systematic strategy, and more than ever it is important to adopt such an approach in the control of the BLSD. Particularly this strategy should be used wherever it is possible, and particularly where fungicide resistance does not prevent it. This assumption should be especially considered in the frame of new banana projects either in traditional banana growing countries (Cameroon, Ivory Coast,....) or in new banana growing countries (Mozambique, Angola, China....)

It is clear that any failure in the implementation of one component of the system is condemning all the system, jeopardizing any effort done in the implementation of any other components.

For instance, if the inoculum density is becoming too high, due to some failure in leaf removal, in the control of "hotspots", or in the timing of the sprays, the effectiveness of the control will be strongly reduced. Thus, the control strategy would not be able to reduce the inoculum density which will continue to increase, if nothing is done to cut such an amplifying effect. In such a situation, the priority is to reduce drastically the inoculum density through appropriate measures (strong leaf removal, systematic applications with contact fungicides to prevent the emergence of resistant strains to systemic fungicides...) and to consider that it is an essential punctual investment necessary for the sustainability of this strategy. The potential benefit of a temporary shift to a systematic use of protectants is probably the most important lesson that should be learnt from the experience in Cameroon, and specific adaptations of the strategy must be adopted in order to manage efficiently fungicide resistance and thus the sustainability of this system that relies on systemic fungicides.

Taking into account that such a control strategy is dealing with a pathogen with a high evolutionary potential, there could not be any "routine" behavior. On the contrary a permanent "alert" behavior is needed to anticipate any new evolution. The control strategy must be shaped to be prepared to evolve and adapt to new constraints.

It is the case with the emergence of resistant strains to curative fungicides, which requires permanent efforts for fungicide resistance management and also to bring curative fungicides with new mode of action. It is also the case with the increasing social pressure related to environment and health in production areas. In this context, it will be probably essential, in the future, to consider the use of resistant varieties to BLSD, at least in certain critical situations (residential areas, hotspots,...). A permanent innovation is the corollary of an integrated and sustainable approach to control the Black Leaf Streak Disease of bananas. It is the reason why a strong interaction must be kept between the technical services in charge of its implementation and research teams able to provide support for anticipation and adaptation.

\section{Acronyms}

AA: diploid Acuminata

AAA: triploid Acuminata

BGA: Banana Growers Association 
BLSD: Black Leaf Streak Disease

CARBAP : Centre Africain de Recherches sur Bananiers et Plantains

CIRAD: Centre de Cooperation Internationale en Recherche Agronomique pour le Développement.

FRAC: Fungicide Resistance Action Committee

FWI: French West Indies

GPS: Global Positioning System

IBS: Inhibitors of ergosterol biosynthesis

IFAC: Institut Français de Recherches Fruitières Outre-Mer

IRFA: Institut de Recherche sur les Fruits et Agrumes

LER : leaf emission rate

Mt : Million tons

NLH: number of functional leaves at harvest

PE: Piche evaporation

SEDb: The Stage of Evolution of the Black Leaf Streak Disease

SEDs : the Stage of Evolution of the Sigatoka Disease

SLSD: Sigatoka Leaf Spot Disease

YLS: the youngest leaf spotted

YLSt: the youngest leaf bearing streaks

\section{References}

Abadie, C., Hubert, O., Ngando Essoh, J., Ngoh, G., Mbéguié-A-Mbéguié, D., de Lapeyre de Bellaire, L., Chillet, M. (2008). Evidence of the effects of Mycosphaerella leaf spot diseases on fruit quality. In: C. N. J.S. Borja, C. Orrantia, R. Paladines, V. Quimí, L. Tazán, (Ed.), XVIIIth ACORBAT meeting, 10-14 November 2008, Guayaquil, Ecuador.

Abadie, C., Chilin-Charles, Y., Huat, J., Salmon, F., Pignolet, L., Carlier, J., Lescot, T., Côte, F., Jenny, C. (2009). New approaches to select cultivars of banana with durable resistance to Mycosphaerella leaf spot diseases. Acta Horticulturae, Vol.828, pp. 171178

Beveraggi, A., Mourichon, X., Salle, G. (1995). Comparative study of the first stages of infection in sensitive and resistant banana plants with Cercospora fijiensis (Mycosphaerella fijiensis), responsible for Black Leaf Streak

Disease, Can. J. Bot., Vol. 73, pp. 1328-1337

Brun, J. (1963).La Cercosporiose du bananier. Thèse Doctorat d'Etat, Université de Paris

Bureau, E., Ganry, J., Zapater, M. F., Laville, E. (1982). Les cercosporioses du bananier et leurs traitements. Evolution des populations pathogènes. Distribution géographique et évolution des populations de Mycosphaerella musicola résistantes aux benzimidazoles dans les zones bananières de Guadeloupe. Fruits, Vol.37, pp. 665-672

Bureau, E., Ganry, J. (1987). A climatic forecasting system to control banana Sigatoka (Mycosphaerella fijiensis), using sterol-biosynthesis inhibiting fungicides. Fruits, Vol.42, pp. 199-205

Bureau, E. (1990). Adaptation d'un système d'avertissement à la lutte contre la cercosporiose noire (Mycosphaerella fijiensis Morelet) en plantation de banane plantain au Panama. Fruits, Vol.45, pp. 329-338 
Carlier, J., Fouré, E., Gauhl,F., Jones, D. R., Lepoivre, P., Mourichon, X., Pasberg-Gauhl, C., Romero, R.A. (2000). Fungal diseases of the foliage - Sigatoka Leaf Spots, in "Diseases of banana, abaca and Ensete", D.R. Jones, cabi Publishing, U.K., 37-91

Chillet, M., Abadie, C., Hubert, O., Chilin-Charles, Y., De Lapeyre de Bellaire, L. (2009). Sigatoka disease reduces the greenlife of bananas. Crop Protection, Vol.28, pp. 41-45

Cuillé, J., Guyot, H. (1956). Les traitements aériens en bananeraie contre Cercospora musae. Fruits, Vol. 11, pp. 435-441

Cuillé, J., Blanchet, B. (1958). Les huiles de traitements, leur phytotoxicité. Fruits, Vol.13, pp. 53-65

Daniells, J.W., Lisle, A.T., Bryde, N.J. (1994). Effect of bunch trimming and leaf removal at flowering on maturity bronzing, yield, and other aspects of fruit-quality of bananas in North Queensland, Aust. J. Exp. Agric., Vol. 34, pp. 259-265

de Lapeyre de Bellaire, L. (2006). Belize, disease monitoring and management exper FWC Lot 1/2005/111696. Report for mission 1: 22 January to 5 February 2006. Cirad, Montpellier, France. 25 p.

de Lapeyre de Bellaire, L. (2007). Belize, disease monitoring and management exper FWC Lot 1/2005/111696. Report for mission $5: 16 / 04$ to 28/4/2007. Cirad, Montpellier, France. $120 \mathrm{p}$.

de Lapeyre de Bellaire, L., Essoh Ngando, J., Abadie, C., Chabrier, C., Blanco, R., Lescot, T., Carlier, J., Côte, F.(2009). Is chemical control of Mycosphaerella foliar diseases of bananas sustainable? Acta Hortic., Vol. 828, pp. 161-170

de Lapeyre de Bellaire, L., Fouré, E., Abadie, C., Carlier, J. (2010a). Black leaf streak disease is challenging the banana industry, Fruits, Vol.65, pp. 327-342

de Lapeyre de Bellaire, L., Ngando, J. E., Rieux, A., Carlier, J., Ravigné, V., Zapater, M.F., Careel, F. (2010b). Etude sur les conditions de réintroduction des fongicides systémiques dans les programmes de lutte contre la maladie des raies noires au Cameroun dans la zone de production de la banane dessert d'exportation : Rapport narratif final $\mathrm{N}^{\circ} 9$ décembre 2010 . Douala : CARBAP, $43 \mathrm{p}$.

Dens, K.R., Romero, R.A., Swennen, R., Turner, D.W. (2008). Removal of bunch, leaves, or pseudostem alone, or in combination, influences growth and bunch weight of ratoon crops in two banana cultivars, J. Hortic. Sci. E Biotechnol. Vol. 83, pp. 113-119

Diaz, E. (1986). Una alternativa de solucion al problema de la Sigatoka negra en la produccion de platanos en Panama, Carta Bananera, No.2-3, pp. 29-32

Eckstein, K., Robinson J.C., Davie S.J. (1995). Physiological responses of banana (Musa-AAA, Cavendish subgroup) in the subtropics. 3. Gas-exchange, growth analysis and source-sink interaction over a complete crop cycle, J. Hortic. Sci., Vol.70, pp. 169180

Fouré, E. (1982a). Les cercosporioses du bananier et leurs traitements. Comportement des variétés. Études de la sensibilité variétale des bananiers et plantains à Mycosphaerella fijiensis Morelet au Gabon (maladie des raies noires). I. Incubation et évolution de la maladie. Fruits, Vol.37, pp. 749-759

Fouré, E. (1982b). Les cercosporioses du bananier et leurs traitements. Comportement des variétés. Etude de la sensibilité variétale des bananiers et plantains à Mycosphaerella fijiensis Morelet au Gabon (maladie des raies noires). II- Etude de quelques paramètres. Fruits, Vol.37, pp. 760-771 
Fouré,E.(1982c).La maladie des raies noires des bananiers et plantains M.fijiensis (Morelet) Etude comparée des différents symptômes et stades de la maladie au Gabon IRFA-CIRAD-France et SONADECI-Gabon

Fouré, E. (1983). Les cercosporioses du bananier et leurs traitements. Sélection de molécules fongicides nouvelles. Activités comparées de différentes molécules fongicides sur Mycosphaerella fijiensis Morelet, agent de la 'maladie des raies noires' des bananiers et plantains au Gabon. Fruits, Vol.38, pp. 21-34

Fouré, E. (1984). Les cercosporioses du bananier et leurs traitements. Sélection de molécules fongicides nouvelles. Activités comparées de différentes molécules fongicides sur Mycosphaerella fijiensis Morelet, agent de la maladie des raies noires des bananiers et plantains du Gabon. (suite IV). Fruits, Vol.39, pp. 753-765

Fouré, E., Grisoni, M. (1984). Les cercosporioses du bananier et leurs traitements. Sélection de molécules fongicides nouvelles. Activités comparées de différentes molécules fongicides sur Mycosphaerella fijiensis Morelet, agent de la maladie des raies noires des bananiers et plantains du Gabon. (suite III). Fruits, Vol.39, pp. 427-440

Fouré, E., Grisoni, M., Zurfluh, R. (1984). Les cercosporioses du bananier et leurs traitements. Comportement des variétés. Etude de la sensibilité variétale des bananiers et plantains à Mycosphaerella fijiensis Morelet et de quelques caractéristiques biologiques de la Maladie des raies noires au Gabon. Fruits, Vol.39, pp. 365-378

Fouré, E. (1985). Les cercosporioses du bananier et leurs traitements. Comportement des variétés. Etude de la sensibilité variétale des bananiers et plantains à Mycosphaerella fijiensis Morelet au Gabon (maladie des raies noires). suite III. Fruits, Vol.40, pp. 393-399

Fouré, E. (1988a). Activités comparées de différentes molécules fongicides sur Mycosphaerella fijiensis, agent de la maladie des raies noires des bananiers et plantains au Cameroun. Fruits, Vol.43, pp. 15-19

Fouré, E. (1988b). Les cercosporioses du bananier et leurs traitements. Efficacités comparées du pyrazophos et du triadiménol sur Mycosphaerella fijiensis Morelet (agent de la cercosporiose noire des bananiers et des plantains au Cameroun) lors de traitements sur grandes surfaces. Fruits, Vol.43, pp. 143-147

Fouré, E. (1988c). Stratégies de lutte contre la cercosporiose noire des bananiers et des plantains provoquée par Mycosphaerella fijiensis Morelet. L'avertissement biologique au Cameroun. Evaluation des possibilités d'amélioration. Fruits, Vol.43, pp. 269-274

Fouré,E.,Mouliom Pefoura,A.(1988).Les cercosporioses des bananiers et leurs traitements.Efficacités comparées de différentes molécules fongicides sur Mycosphaerella fijiensis Morelet, agent de la Maladie des Raies Noires des bananiers et des plantains au Cameroun. Fruits, Vol.43, N³, pp 67-72

Fouré, E, Lescot, T. (1988) Variabilité génétique des Mycosphaerella inféodés au genre Musa. Mise en évidence de la présence au Cameroun sur bananiers et plantains d'une cercosporiose (Mycosphaerella musicola) au comportement pathogène atypique, Fruits, Vol.43, No7, 8, pp. 407-415

Fouré, E, Mouliom, Pefoura A, Mourichon, X. (1990). Etude de la sensibilité des bananiers et des plantains à M.fijiensis Morelet au Cameroun. Caractérisation de la résistance au champ de bananiers appartenant à divers groups génétiques. Fruits, Vol.45, No.4, pp. 339-345 
Fouré,E.,Moreau,A.(1992).Contribution à l'étude épidémiologique de la cercosporiose noire dans la zone bananière du Mungo de 1987 à 1989. Fruits, Vol.47, N¹, pp.3-16

Fouré, E., Ganry, J. (2008). A biological forecasting system to control Black Leaf Streak disease of bananas and plantains. Fruits, Vol.63, pp. 311-317

FRAC. 2004. Recommendations of the FRAC Banana Working Group: www.frac.info

Frossard, P. (1980). Apparition d'une nouvelle et grave maladie foliaire des bananiers et plantains au Gabon : la maladie des raies noires : Mycosphaerella fijiensis Morelet. Fruits, Vol.35, pp. 519-527

Fullerton, R., Olsen, T. (1995). Pathogenic variability in Mycosphaerella fijiensis Morelet cause of black Sigatoka in banana and plantain. New Zealand Journal of Crop and Horticultural Science, Vol.23, pp. 39-48

Ganry, J., Meyer, J. P. (1972). La lutte contrôlée contre le cercospora aux Antilles. 1-Bases climatiques de l'avertissement. Fruits, Vol.27, pp. 665-676

Ganry, J., Meyer, J-P. (1972). La lutte contrôlée contre le Cercospora aux Antilles. Technique d'observation et de numérotation de la maladie, Fruits, Vol.27, pp. 767-774

Ganry, J., Laville, E. (1983). Les cercosporioses du bananier et leurs traitements. 1Traitements fongicides. 2- Avertissement. Fruits, Vol.38, pp. 3-20.

Ganry,J. (2001). Maitrise de la culture du bananier pour une production raisonnée face aux nouveaux défis, C.R. Acad. Agric. Fr., Vol.87, No.6, pp. 119-127

Ganry, J. (2004). Specific diversity of plant populations at rainfed scale and crop protection: the example of banana production in the French West Indies. Comptes rendus Biologies, Vol.327, No.7, pp. 621-627

Ganry J., Lapeyre de Bellaire L., Mourichon X., 2008. A biological forecasting system to control Sigatoka leaf spot of bananas and plantains, Fruits, Vol.63, pp. 381-387

Guyot, H., Cuillé,J. (1954).Les formules fongicides huileuses pour le traitement des bananeraies, Fruits, Vol.9, No.7, pp. 289-292

Guyot, H., Cuillé,J. (1955). Les traitements fongicides des bananeraies - Efficacité des différents modes de traitement - Rôle de l'huile, Fruits, Vol.10, No.3, pp. 101-107

Henderson, J., Pattemore, J. A., Porchun, S. C., Hayden, H. L., Van Brunschot, S., Grice, K. R. E., Peterson, R. A., Thomas-Hall, S. R., Aitken, E. A. B. (2006). Black Sigatoka disease: new technologies to strengthen eradication strategies in Australia. Australasian Plant Pathology, Vol.35, pp. 181-193

Jones, D.R. (2000). Diseases of banana, abaca and ensete, CAB Int., Wallingf., UK

Jimenez, F., Tapia, A. C., Gribius, N., Escalant, J. V. (1995). Relation entre la durée de pluie et le développement de la cercosporiose noire sur le bananier plantain. Proposition d'un système d'avertissement biométéorologique. Fruits, Vol.50, pp. 87-99

Karaoglanidis G.S., Thanassoulopoulos C.C., Ioannidis P.M. (2001). Fitness of Cercospora beticola field isolates - resistant and - sensitive to demethylation inhibitor fungicides. European Journal of Plant Pathology, Vol.107, pp.337-347

Lescot, T., Simonot, H., Fages,O., Escalant, J.V. (1998). Avertissement biométéorologique pour lutter contre la cercosporiose noire en plantations de banane plantain au Costa Rica. Fruits, Vol.53, pp. 3-16.

Lescot, T. (2011). La diversité génétique des bananiers, FruiTrop Vol.89, pp. 58-62

Loeillet, D. (2005). Le commerce international de la banane : entre évolution et révolution, Frui-Trop, Vol.129, pp. 2-19 
Marin, D.H., Corrales, O. (1992). Sistema de preaviso simplificado para el combate de la Sigatoka Negra en platano, in Corporacion Bananera Nacional, Informe Anual 1991, san José, Costa-Rica, pp. 90-91

Marin, D.H.,Romero, R.A.,Guzmàn, M., Sutton, T.B. (2003). Black Sigatoka : An Increasing Threat to Banana Cultivation, Plant Disease, Vol.87, No. 3, pp. 208-222

Mobambo, K.N., Gauhl, F., Pasberg-Gauhl, C., Zuofa, K. (1996). Season and plant age effect evaluation of plantain for response to black sigatoka disease, Crop Prot. Vol.15

Pennisi ,E. (2010). Armed and dangerous, Science, Vol.327, pp. 804-805

Ramsey, M.D., Daniells, J.W., Anderson, D.J. (1990). Effects of Sigatoka leaf spot (Mycosphaerella musicola Leach) on fruit yields, field ripening and greenlife of bananas in North Queensland, Sci. Hortic. Vol.41, pp. 305-313

Risède, J.M., Lescot, T., Cabrera Cabrera, J., Guillon, M., Tomekpé, K., Kema, G.H.J., Côte, F. (2010). Challenging short and mid-term strategies to reduce pesticides in bananas. [Online]. [S.1.] : ENDURE, [8] p. (Banana Case Study - Guide, 1).

Romero, R. A., Sutton, T. B. (1997). Sensitivity of Mycosphaerella fijiensis, causal agent of Black Sigatoka of Banana, to Propiconazole. Phytopathology, Vol.87, pp. 96-100

Stover, R.H. (1971). A proposed international scale for estimating intensity of banana leaf spot (Mycosphaerella musicola Leach),Trop. Agric., Vol.48, pp. 185-196

Stover, R.H. (1972). Banana, plantain and abaca diseases, Commonw. Mycol. Inst., Kew, Surrey, UK

Stover, R.H. (1983). Effet du cercospora noir sur les plantains en Amérique centrale, Fruits Vol.38, pp. 326-329

Stover, R.H. (1986). Disease management strategies and the survival of the banana industry. Annual Review of Phytopathology, Vol.24, pp. 83-91

Stover, R.H., Simmonds, N.H. (1987). Bananas, 3 ${ }^{\text {rd }}$ edit. Longman Scientific and Technical, Harlow, Essex. UK, 468 pp

Vargas, A., Araya M., Guzman M., Murillo G. (2009). Effect of leaf pruning at flower emergence of banana plants (Musa AAA) on fruit yield and black Sigatoka (Mycosphaerella fijiensis) disease, Int. J. Pest Manag., Vol.55, pp. 19-25 


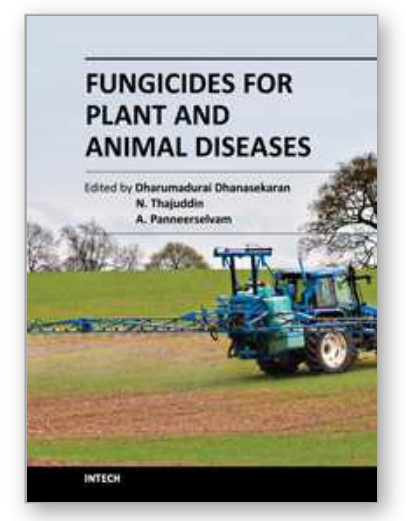

\author{
Fungicides for Plant and Animal Diseases \\ Edited by Dr. Dharumadurai Dhanasekaran
}

ISBN 978-953-307-804-5

Hard cover, 298 pages

Publisher InTech

Published online 13, January, 2012

Published in print edition January, 2012

A fungicide is a chemical pesticide compound that kills or inhibits the growth of fungi. In agriculture, fungicide is used to control fungi that threaten to destroy or compromise crops. Fungicides for Plant and Animal Diseases is a book that has been written to present the most significant advances in disciplines related to fungicides. This book comprises of 14 chapters considering the application of fungicides in the control and management of fungal diseases, which will be very helpful to the undergraduate and postgraduate students, researchers, teachers of microbiology, biotechnology, agriculture and horticulture.

\title{
How to reference
}

In order to correctly reference this scholarly work, feel free to copy and paste the following:

Jacky Ganry, Eric Fouré, Luc de Lapeyre de Bellaire and Thierry Lescot (2012). An Integrated Approach to Control the Black Leaf Streak Disease (BLSD) of Bananas, while Reducing Fungicide Use and Environmental Impact, Fungicides for Plant and Animal Diseases, Dr. Dharumadurai Dhanasekaran (Ed.), ISBN: 978-953307-804-5, InTech, Available from: http://www.intechopen.com/books/fungicides-for-plant-and-animaldiseases/an-integrated-approach-to-control-the-black-leaf-streak-disease-blsd-of-bananas-while-reducingfungi

\section{INTECH}

open science | open minds

\section{InTech Europe}

University Campus STeP Ri Slavka Krautzeka 83/A 51000 Rijeka, Croatia Phone: +385 (51) 770447 Fax: +385 (51) 686166 www.intechopen.com

\author{
InTech China \\ Unit 405, Office Block, Hotel Equatorial Shanghai \\ No.65, Yan An Road (West), Shanghai, 200040, China \\ 中国上海市延安西路65号上海国际贵都大饭店办公楼405单元 \\ Phone: +86-21-62489820 \\ Fax: +86-21-62489821
}


(C) 2012 The Author(s). Licensee IntechOpen. This is an open access article distributed under the terms of the Creative Commons Attribution 3.0 License, which permits unrestricted use, distribution, and reproduction in any medium, provided the original work is properly cited. 